\title{
Measuring the Interaction Between the Macro- and Micro-Vasculature
}

\author{
Rachel E. Climie ${ }^{1,2,3 *}$, Antonio Gallo ${ }^{4,5}$, Dean S. Picone ${ }^{3}$, Nicole Di Lascio ${ }^{6}$, \\ Thomas T. van Sloten ${ }^{1,7}$, Andrea Guala ${ }^{8}$, Christopher C. Mayer ${ }^{9}$, Bernhard Hametner ${ }^{9}$ and \\ Rosa Maria Bruno ${ }^{1}$ \\ ${ }^{1}$ INSERM, U970, Paris Cardiovascular Research Center (PARCC), Paris Descartes University, Paris, France, ${ }^{2}$ Baker Heart \\ and Diabetes Institute, Melbourne, VIC, Australia, ${ }^{3}$ Menzies Institute for Medical Research, University of Tasmanian, Hobart, \\ TAS, Australia, ${ }^{4}$ Cardiovascular Prevention Unit, Department of Endocrinology and Metabolism, Pitié-Salpêtrière Hospital, \\ Paris, France, ${ }^{5}$ Laboratoire d'imagerie Biomédicale, INSERM 1146 - CNRS 7371, Sorbonne University, Paris, France, \\ ${ }^{6}$ Institute of Clinical Physiology, National Research Council, Pisa, Italy, ${ }^{7}$ Cardiovascular Research Institute Maastricht and \\ Department of Internal Medicine, Maastricht University Medical Centre, Maastricht, Netherlands, ${ }^{8}$ Department of Cardiology, \\ Hospital Universitari Vall d'Hebron, Vall d'Hebron Institute of Research, Barcelona, Spain, ${ }^{9}$ AlT Austrian Institute of \\ Technology GmbH, Center for Health \& Bioresources, Biomedical Systems, Vienna, Austria
}

\section{OPEN ACCESS}

Edited by:

Isabella Sudano,

University Hospital Zürich, Switzerland

Reviewed by:

Damiano Rizzoni,

University of Brescia, Italy

Belen Ponte,

Geneva University Hospitals

(HUG), Switzerland

*Correspondence:

Rachel E. Climie

Rachel.Climie@inserm.fr

Specialty section:

This article was submitted to

Hypertension

a section of the journal

Frontiers in Cardiovascular Medicine

Received: 17 September 2019

Accepted: 07 November 2019

Published: 22 November 2019

Citation:

Climie RE, Gallo A, Picone DS, Di Lascio N, van Sloten TT, Guala A,

Mayer CC, Hametner $B$ and

Bruno RM (2019) Measuring the Interaction Between the Macro- and

Micro-Vasculature.

Front. Cardiovasc. Med. 6:169. doi: 10.3389/fcvm.2019.00169
Structural and functional dysfunction in both the macro- and microvasculature are a feature of essential hypertension. In a healthy cardiovascular system, the elastic properties of the large arteries ensure that pulsations in pressure and flow generated by cyclic left ventricular contraction are dampened, so that less pulsatile pressure and flow are delivered at the microvascular level. However, in response to aging, hypertension, and other disease states, arterial stiffening limits the buffering capacity of the elastic arteries, thus exposing the microvasculature to increased pulsatile stress. This is thought to be particularly pertinent to high flow/low resistance organs such as the brain and kidney, which may be sensitive to excess pressure and flow pulsatility, damaging capillary networks, and resulting in target organ damage. In this review, we describe the clinical relevance of the pulsatile interaction between the macro- and microvasculature and summarize current methods for measuring the transmission of pulsatility between the two sites.

Keywords: methods, microvascular, macrovascular, wave intensity analysis, brain, kidney, retina

\section{INTRODUCTION}

High blood pressure (BP; hypertension), is the leading modifiable risk factor for the global burden of disease (1) and accounts for 9.4 million deaths worldwide each year (2), mostly due to cardiovascular disease (CVD) (3). Associated with raised BP is structural and functional dysfunction in both the macro- and microvasculature. In the macrovasculature this manifests as an increase in intima-media thickness (IMT) (4-7), accompanied by lumen enlargement (5-7) and increased stiffness in proximal elastic arteries (8) but not in distal muscular arteries (4-6). In the microvasculature, vasoconstriction, eutrophic remodeling (characterized by increased media-to-lumen ratio or wall-to-lumen ratio with no change in cross-sectional wall area) (9), alterations in distensibility, decreased vasodilatory reserve and rarefaction are evident in those with essential hypertension (10-12). Such changes in the vessels are likely to play a contributory role to hypertension-related organ damage and elevated CVD risk. 
In a healthy cardiovascular system, the elastic properties of the large arteries ensure that pulsations in pressure and flow generated by cyclic left ventricular contraction are dampened, so that less pulsatile pressure and flow are delivered at the microvascular level. However, in response to aging $(13,14)$, hypertension and other disease states such as dyslipidemia and diabetes mellitus $(15,16)$, arterial stiffening limits the buffering capacity of the elastic arteries, thus exposing the microvasculature to increased pulsatile stress $(17,18)$. This is thought to be particularly pertinent to high flow/low resistance organs such as the brain and kidney, which may be sensitive to excess pressure and flow pulsatility, damaging capillary networks and resulting in target organ damage (1924) (Figure 1). However, to our knowledge, few studies (2527) have examined the macro- and micro-vasculature directly to determine whether there is transmission of pulsatility. This is an opportunity for future work as understanding the interaction between the macro- and microvasculature will provide targets for future treatment and management strategies aimed at limiting the pulsatility transmission to target organs, thus reducing target organ damage and ultimately improving clinical outcomes. In this review, we describe the clinical relevance of the pulsatile interaction between the macro- and microvasculature and summarize current methods for measuring the transmission of pulsatility between the two sites.

\section{CLINICAL RELEVANCE OF THE PULSATILE INTERACTION BETWEEN THE MACRO- AND MICRO-VASCULATURE}

The function of the aorta is to receive blood from the left ventricle and supply it to the systemic circulation. The proximal aorta achieves this by expanding during systole, which is made possible due to the highly elastic wall structure. The reservoir effect of the aorta allows a portion of the stroke volume ejected during systole to be temporarily stored and then propelled to the systemic circulation during diastole via recoil of the elastic arterial wall. Otherwise known as the Windkessel effect, this allows the aorta to provide continuous blood flow to the systemic circulation throughout the cardiac cycle and ensures the pulsatility of flow is reduced by the buffering effect of the reservoir (18). However, this reservoir function is highly dependent on (a) the stiffness and (b) the geometry of the arteries $(28,29)$, and is reduced in disease states.

(a) Arterial stiffness refers to the level of arterial compliance and vessel wall properties. A stiffer aorta will have a reduced reservoir capacity and a larger proportion of the ejected stroke volume will flow through the arterial system during systole, resulting in both intermittent pressure and flow as well as excessive pressure and flow pulsatility. This may contribute to target organ damage via remodeling, capillary

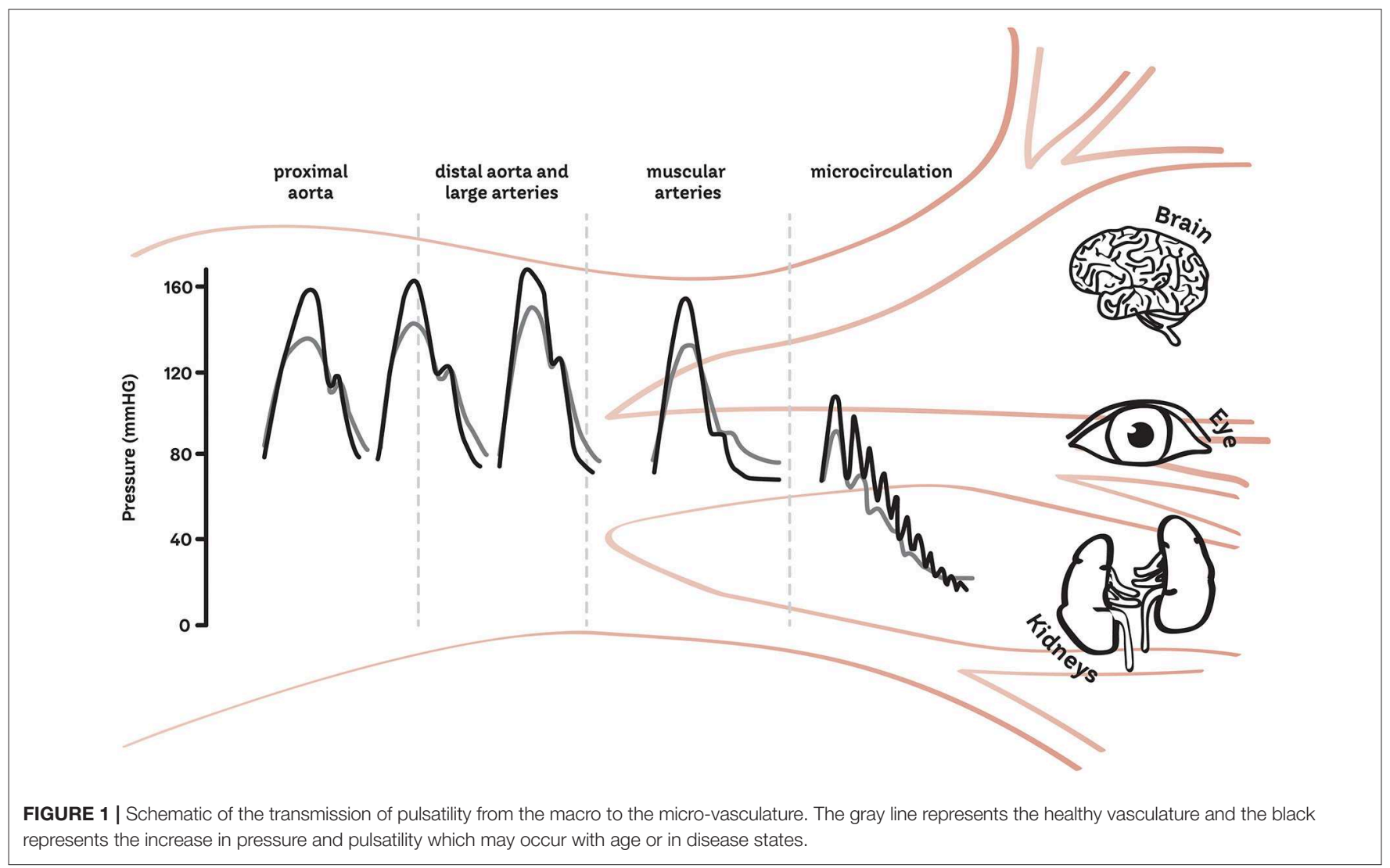


rarefaction, and microvascular ischemia (30). The gold standard method to non-invasively quantify arterial stiffness is carotid-femoral pulse wave velocity (cfPWV). cfPWV is the quantification of time delay between carotid and femoral waveforms, divided by the distance covered. Other methods for measuring PWV in the large arteries exist including cuffbased techniques and phase-contrast magnetic resonance imaging (MRI). Moreover, other parameters, such as aortic strain and distensibility may provide an alternative description of large artery stiffness (31).

(b) The enlargement of the large arteries (i.e., thoracic aorta and common carotid artery) with aging and hypertension is generally due to the fracture of the load-bearing elastin fibers due to the fatiguing effect of both the steady and pulsatile tensile stress. Vascular smooth muscle cell (VSMC) growth and apoptosis may also be involved, as the cyclic, pulsatile strain on the vessels is also a determinant of gene expression and growth of VSMCs in vitro $(32,33)$. The enlargement of large proximal arteries is suggested to be a compensating mechanism, ensuring that a certain level of arterial compliance is maintained (29, 34, 35). However, when excessive (aneurysm), it may lead to major adverse aortic events such as dissection and rupture (36). Interestingly, the effect of pulsatile mechanical load on arterial remodeling has been observed in large elastic arteries but not in more distal, muscular arteries (radial). Large artery dimension and shape can be quantified non-invasively by MRI and ultrasound.

\section{The Brain}

Recent work suggests that aortic stiffness and pulsatile hemodynamics are related to cerebral small vessel disease development $(30,37-41)$. Cerebral small vessel disease is a range of neuroimaging findings (including white matter hyperintensities and lacunes of presumed vascular origin, cerebral microbleeds, perivascular spaces, and total cerebral atrophy) thought to arise from disease affecting the perforating cerebral arterioles, capillaries and venules, and the resulting brain damage in the cerebral white and deep gray matter (42). In the Age, Gene/Environment Susceptibility (AGES)Reykjavik study, higher aortic stiffness was associated with an increase in flow pulsatility transmission to the cerebrovascular circulation (30). In middle-aged and older adults, aortic stiffness and pressure pulsatility were associated with progression of neurovascular disease and cognitive decline (43). The association between mean blood flow and its pulsatility and mild cognitive impairment was also reported in a cross-sectional study (44) based on $4 \mathrm{D}$ flow MRI, the reference technique for flow evaluation especially in complex vascular territories, such as inside the skull. Additionally, excess pressure, analogous to left ventricular flow, was related to gray matter atrophy in healthy subjects (45).

\section{The Kidney}

The relationship between arterial stiffness and pulsatility in the kidneys has been demonstrated in several observational studies [summarized in (46)]. These studies evaluated the association between arterial stiffness and chronic kidney disease progression, with conflicting results in those with type 2 diabetes (T2D) (47, 48), hypertension (49), elderly (50), healthy middle-aged (51, 52), and young adults (53). Interestingly, in both middle age and elderly subjects, an increase in brachial pulse pressure was associated with accelerated renal function decline $(50,52)$ and in patients with $\mathrm{T} 2 \mathrm{D}$, excess pressure was related to exercise-induced albuminuria (24). However, the most convincing evidence on the clinical relevance of the macro-microvascular interaction for kidney function comes from a cross-sectional analysis of the AGES study cohort (54). In 367 older adults aged 72-92 years, a mediation analysis demonstrated that $34 \%$ of the relationship between aortic stiffness and estimated glomerular filtration rate (eGFR) was mediated by increased pulsatility index in the renal artery, assessed via MRI flow waveform measurements. Aortic stiffness was found to induce kidney damage mostly by means of an increased flow pulsatility transmission (54). Interestingly, high pulsatility mediates PWV-induced eGFR decline but the effect on microalbuminuria accrual is less clear. Thus, it is conceivable that the deleterious macro- microvascular interaction in diseases such as T2D may be responsible for the increasingly higher prevalence of normoalbuminuric/eGFR decline, an emerging phenotype in contemporary epidemiology of diabetic nephropathy (55). However, this hypothesis needs to be tested in future studies.

\section{The Retina}

The retina is a unique site where the microcirculation can be imaged directly, providing an opportunity to study in vivo the structure and pathology of the human circulation. The retina is characterized by a dual blood supply: the inner layers are supplied by the retinal arteries derived from the central retinal artery; the outer retina, being avascular, depends on choroidal circulation (56). These two vascular systems being completely independent, present specific anatomical and physiological characteristics, resulting in higher perfusion rate in the choroidal vasculature and higher resistance at the inner retinal level (57). As a consequence, the outer retinal layers may be more exposed, and damaged by increased flow pulsatility related to increased large artery stiffness, although this hypothesis needs to be confirmed. Large artery stiffness has been shown to be related to diabetic retinopathy (58), age-related macular degeneration (59) and retinal microvascular impairment (60, 61). Exaggerated pulsed retinal capillary flow, in contrast to unchanged mean retinal capillary flow, and stiffer wall properties of retinal arterioles has been observed in patients with treated resistant hypertension compared with patients with grade 12 hypertension (62). Furthermore, retinal PWV discriminated between patients with mild hypertension and those with normal or high normal BP $(63,64)$ and may be related to large artery PWV.

\section{THE MACROVASCULATURE AND PULSATILE HEMODYNAMICS}

With advancing age, there is gradual degradation and fracture of the elastin fibers in the arterial wall, leading to dilation, and 
stiffening of large elastic arteries (aorta, carotid). In a study of aortic sections from a range of animal species, a higher number of cardiac cycles across the lifespan (heart rate $\mathrm{x}$ age) were associated with greater disorganization of elastin, demonstrating how the stress of each heart beat gradually alters arterial wall structure causing loss of aortic buffering function (65), in a process often assimilated to material fatigue due to cyclic stress. Thus, aortic stiffness seems to precede, and induce, pulse pressure elevation and hypertension (66-69). In parallel, sustained increases in BP lead to changes to smooth muscle cell organization and the extra-cellular matrix, resulting in greater arterial stiffness $(70,71)$.

The relation between vessel geometry and distensibility and local pulse pressure is highly debated. In a multivariable analysis of a cohort of normotensive, and treatment-naïve hypertensive patients, common carotid artery diameter and carotid IMT were positively related to carotid pulse pressure, as well as heart rate and age (7). Accordingly, a cross-sectional MRI study of 100 apparently healthy adults showed aortic dilation, elongation, and reduced curvature in older age. Each of the geometric changes were strongly related to higher systolic BP $(72,73)$. In contrast other data, such as the 16-year follow up from the Framingham Heart Study and the 20-year follow-up from the Healthy Coronary Artery Risk Development in Young Adults study $(74,75)$, support the notion that higher central aortic pulse pressure is associated with lower aortic diameter (76-78). Finally, an MRI study in young-middle aged adults with isolated systolic hypertension (and thus elevated pulse pressure), suggested that it is rather the mismatch between aortic stiffness and diameter, which could explain elevated pulsatility (77).

An emerging determinant of increased transmission of pressure and flow pulsatility at the microvasculature level occurring with age and risk factors is the reduced impedance mismatch between large and medium-sized muscular arteries. The impedance is the relationship between pressure and flow. In the context of large arteries, the characteristic impedance is often used to quantify the amount of reflection generated from the passage of a wave. At a location where characteristic impedance changes, often called impedance mismatch, a reflected wave is generated. Larger and more elastic vessels have lower characteristic impedance. According to the so-called stiffness gradient hypothesis, in healthy young individuals, when aortic stiffness is lower than that of medium-sized muscular conduit arteries, some suggest that partial pressure wave reflections are generated at the transition of these segments, resulting in attenuated pulse pressure transmission and possible protection of microcirculation $(34,79)$. By increasing large but not small artery stiffness, aging and risk factors limit or even reverse this gradient, attenuating distal reflection and thus increasing the amount of forward pressure wave transmitted to the microcirculation, potentially leading to increased organ damage. This hypothesis was supported by a prospective study in dialysis patients and demonstrated that a reduced stiffness gradient is associated with increased cardiovascular events (80). Furthermore, a reduced stiffness gradient was observed in patients with T2D (81). However, others have shown that aortic-brachial stiffness gradient had little or no impact on wave reflection (evaluated as augmentation index) and left ventricular hypertrophy (82).

\section{THE MICROVASCULATURE AND PULSATILE HEMODYNAMICS}

The microcirculation has long been thought to only be representative of peripheral vascular resistance (i.e., steady state, as expressed as the ratio between mean arterial pressure and cardiac output). However, the pulsatile component of the BP curve (i.e., pulse pressure) influences the entire arterial tree, including small arteries. Vasoconstriction of the arterioles may increase the amplitude of wave reflection, resulting in an increase in central (aortic) pulse pressure. However, an alternate explanation for an increase in central pulse pressure may be an increase in the forward compression wave (83-85). Conversely, endothelial cells, and pericytes in the microvasculature may respond to increased pulsatile flow by compensatory mechanisms, such as increased production of nitric oxide and activation of cyclooxygenase-2, which are concomitant with endothelin-1 and prostacyclin decrease (86). When nitric oxide availability in the microcirculation is reduced in conditions such as increased oxidative stress (as in aging and hypertension) or hyperglycemia (as in T2D), the impact of large artery flow pulsatility in the microcirculation may be greater (87). The microcirculation also represents the very early site of expression of CVD, by means of a chronic inflammation state. The overexpression of reactive oxygen species leads to an increased myogenic tone and is responsible for microvascular remodeling in hypertension (88). This inflammatory state may be also modulated by peculiar flow conditions, such as an atheroprotective flow that was shown to induce miRNAs, which are involved in the downregulation of pro-inflammatory and upregulation of anti-inflammatory molecules (89).

\section{CROSS TALK BETWEEN THE MACRO- AND MICRO-VASCULATURE AND METHODS TO MEASURE THE INTERACTION}

To investigate the interaction between the macro- and microvasculature, knowledge of the fluid dynamics between these regions in the human body is essential. Following the wave transmission approach, arterial pressure, and flow are the result of superimposing forward and backward traveling waves. Thus, it is desirable to quantify waves traveling in the forward direction from large to small arteries, as well as to quantify reflected waves traveling from the microcirculation back into larger arteries (Figure 2).

Augmentation index (AIx), defined as the difference between the shoulder on the pressure wave and systolic pressure divided by pulse pressure, has been widely used as a measure of wave reflections (29) (Figure 2). An advantage of AIx is its non-dimensionality, requiring neither calibration of BP nor measurement of blood flow velocity. BP waveforms can be obtained using non-invasive tonometry at the location of the carotid- or radial arteries, or by oscillometric BP recordings at the brachial level (90); however the validity of AIx as a measure of reflection is uncertain as it is also influenced by PWV and other 

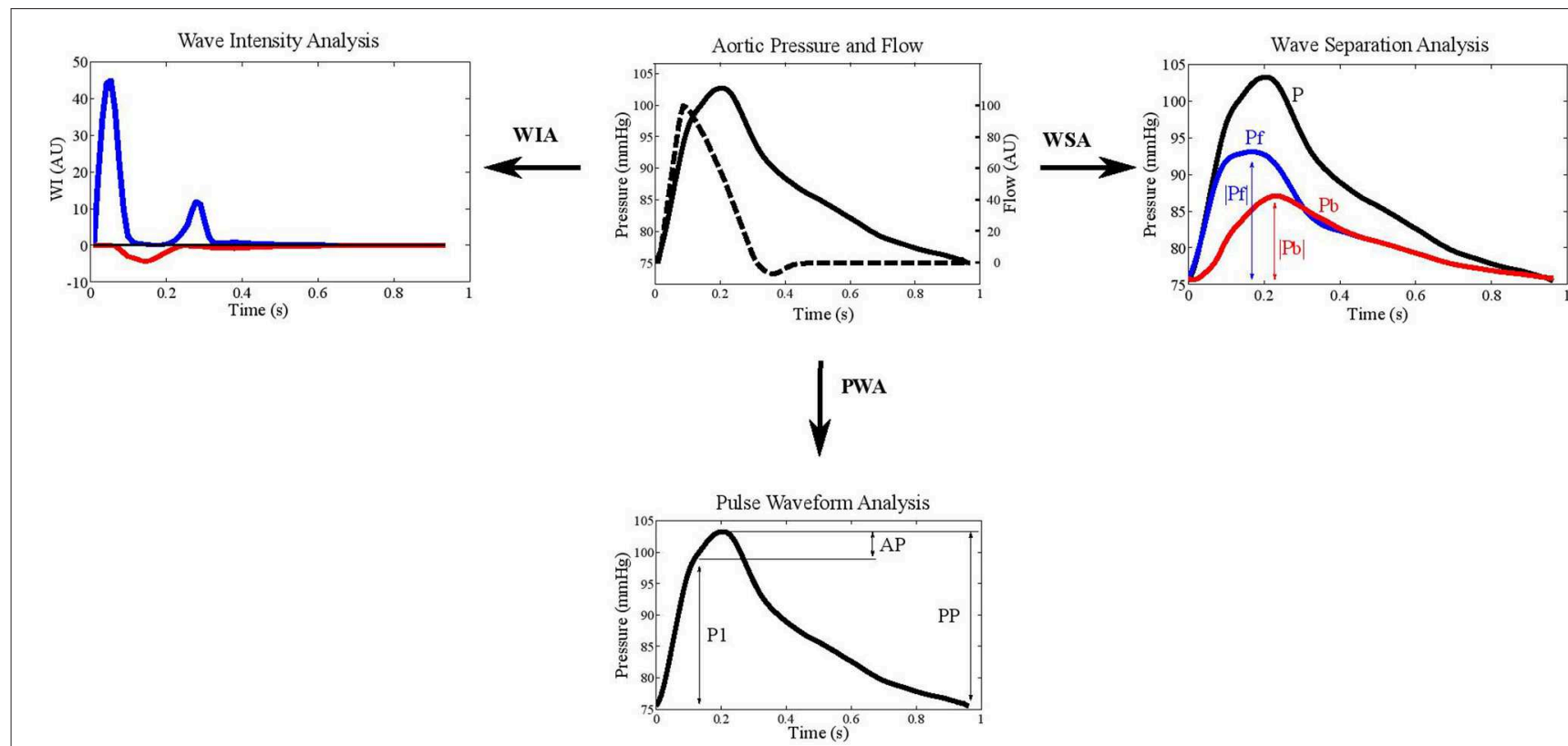

FIGURE 2 | Example aortic pressure and flow waveforms depicted in wave intensity analysis (WIA), wave separation analysis (WSA), and pulse wave analysis (PWA). The blue lines indicate forward pressure $(\mathrm{Pf})$ and the red lines represent backward pressure $(\mathrm{Pb})$. Augmentation index is calculated as augmented pressure (AP) divided by pulse pressure (PP).

factors. It has been suggested that AIx may be more indicative of arterial compliance and reservoir function than wave reflection (91). Indeed, in healthy individuals, no relationship between AIx and the "gold standard" measures of wave reflection calculated from pressure and flow data were found (85). Furthermore, using a computational model of the circulation, it was recently demonstrated that myocardial shortening velocity and large artery stiffness are the main determinants of AIx (92). Thus, despite AIx being used extensively in cardiovascular research and its predictive value for cardiovascular outcomes (93), the available evidence suggests that AIx may not suitably represent the interaction between macro-and microvasculature and supports the use of wave separation and intensity techniques $(94,95)$. Following the wave transmission approach, methods for the separation of pressure, and flow waveforms into their forward and backward components have been presented, and indices for the quantification of meaningful descriptors have been developed (96).

\section{Wave Separation Analysis}

Westerhof et al. introduced the impedance method for wave separation analysis (28) (Figure 2). Assuming a stable cardiovascular condition, the characteristic impedance $Z_{c}$ is estimated in the frequency domain as high frequency limit of the input impedance. Subsequently, forward $\left(\mathrm{P}_{\mathrm{f}}\right)$ and backward $\left(\mathrm{P}_{\mathrm{b}}\right)$ traveling pressure can be expressed, based on measured pressure $(\mathrm{P})$ and flow $(\mathrm{Q})$, as:

$$
\begin{aligned}
\mathrm{P}_{\mathrm{f}} & =\left(\mathrm{P}+\mathrm{Z}_{\mathrm{c}}^{*} \mathrm{Q}\right) / 2 \\
\mathrm{P}_{\mathrm{b}} & =\left(\mathrm{P}-\mathrm{Z}_{\mathrm{c}}^{*} \mathrm{Q}\right) / 2
\end{aligned}
$$

where $\mathrm{P}$ is pressure and $\mathrm{Q}$ is volume flow.

Alternatively, wave separation can also be performed in the time domain. In this case, wave speed instead of wave characteristic impedance is required. Usually, the amplitudes of $\mathrm{P}_{\mathrm{f}}$ and $\mathrm{P}_{\mathrm{b}}$ or their ratio $\mathrm{P}_{\mathrm{b}} / \mathrm{P}_{\mathrm{f}}$, also denoted as reflection magnitude, are used as indices for the quantification of the pressure waves (97). Reflection magnitude showed a strong predictive value both for cardiovascular events and new-onset heart failure in a large community sample (98). In particular, $\mathrm{P}_{\mathrm{f}}$ amplitude has been associated with increased cardiovascular event incidence, beyond traditional risk factors and arterial stiffness (99).

\section{Wave Intensity Analysis}

Wave intensity analysis (WIA) is increasingly employed in the study of the cardiovascular system, providing additional, and complementary information to the standard vascular evaluation (Figure 2). Wave intensity represents the instantaneous power carried by the pulse wave per unit cross sectional area traveling from the heart to the periphery. The energy associated with this wave is the result of the kinetic energy related to the blood flow and the potential energy linked to the expansion of the arterial wall (97).

The WIA implementation requires the acquisition of the pressure and the flow velocity waveforms at a specific arterial site. The wave intensity signal is then obtained by multiplying the time derivative of pressure by the time derivative of blood velocity (100). As a consequence, absolute wave intensity values can characterize the traveling waves in terms of direction, discriminating between forward waves originating from the heart 
and backward ones arising from reflections sites. Furthermore, since different changes in pressure and flow velocity lead to the compression or the expansion of the vessel, both the forward and the backward fronts can be characterized in terms of compression and expansion waves (101).

The WIA signal in the aorta (101) presents a first positive and prevailing peak in the early systolic phase, caused by the simultaneous increasing of pressure and flow velocity originating from left ventricle ejection (102). This local maximum is followed by a small negative peak, generated by concomitant increase in pressure and decrease in blood flow and is representative of the backward compression wave originating from the reflection of the forward compression wave from more distal points (103). Finally, at the end-systolic phase, the wave intensity signal shows a second positive peak, smaller than the first one, and caused by the simultaneous decrease in pressure and flow velocity (forward expansion wave) (102).

The analysis of the wave intensity signal provides quantitative information about the energy transfer along the arterial tree; therefore, this approach may be useful for obtaining information about the interaction between macro- and microvasculature (104). Currently, most literature concerns the cerebral circulation. WIA was used to assess changes in the cerebral vasomotor tone as a consequence of a hypercapnia status, which is known to alter cerebral resistance. In this study, the amplitude of the negative peak, both considering it as an absolute value or divided by the amplitude of the first positive peak (reflection index), was significantly decreased following increase carbon dioxide concentration, indicating an association between reduction in reflections and cerebral vasodilation (105). This result is in line with other work focused on the effects of two different hypertensive treatments. WIA was employed at the carotid artery level and the WIA-derived reflection index was significantly lower for the treatment with a greater vasodilator action, as a consequence of an improved impedance matching in correspondence of bifurcations (106). In treated hypertensive patients, WIA-derived reflection index, but not reflection magnitude and AIx, predicted cardiovascular events independently of traditional risk factors (107). Furthermore, a recently published longitudinal study showed that the amplitude of the forward traveling wave, as assessed in mid- to late-life at the carotid artery level, predicts faster cognitive decline, independent from other cardiovascular risk factors (108).

Despite this evidence, some technical, and practical issues should be considered. Since invasive assessment of pressure and flow velocity waveforms is not feasible for widespread use (101, 109), non-invasive approaches have been proposed, using applanation tonometry to obtain the pressure curve and ultrasound pulsed wave Doppler imaging for the acquisition of the flow velocity $(104,110,111)$. Alternatively, WIA can be implemented using diameter values instead of pressure following the mathematical theory reported in (112). This method has been applied at both the carotid and femoral artery (113) and represents a valid approach even in preclinical settings involving murine models, in which both the invasive and the standard non-invasive methods are more difficult to implement (114).

\section{Wave Power Analysis}

A drawback of the wave intensity is that it is not a conserved quantity, i.e., it is sensitive to variations in the vessel diameter, leading to difficulties in analyzing wave transmission in the arterial tree. To overcome this problem, Mynard and Smolich proposed the wave power analysis as an alternative (115). To calculate wave power, volume flow instead of flow velocity is used. As for the other methods, forward and backward components of wave power can be derived to investigate wave transmission phenomena. Recently, wave power analysis was used to identify a higher aorto-carotid wave transmission in patients with reduced aortic distensibility after coarctation repair. This is of importance, as it is known that these subjects have an increased risk of cerebrovascular disease and stroke even after successful surgical treatment $(116,117)$. Extensive clinical validation is needed to understand the role of wave power analysis in the panorama of the other techniques assessing wave reflection.

\section{METHODS FOR MEASURING PULSATILITY IN THE MICROVASCULATURE}

Methods for measuring pulsatility in the macrovasculature are displayed in Table 1. Different methods are available to assess the microvascular pulsatile hemodynamics in low-resistance, high flow organs such as the brain (and retina) and the kidneys (Table 2).

\section{The Brain}

Most of the measures of pulsatility in intracranial arteries are based on MRI or transcranial doppler ultrasound.

\section{Cerebral Vasoreactivity}

Cerebral vasoreactivity is a measure for the vasodilatory ability of the cerebral (micro)vasculature and is defined as the mean increase in blood flow or velocity after stimulation with either acetazolamide or $\mathrm{CO}_{2}$ (118). Cerebral vasoreactivity can be measured at the tissue level using blood oxygenation level dependent MRI, arterial spin labeling, or positron emission tomography $(119,120)$. In addition, cerebral vasoreactivity can be determined at the level of the large intracranial arteries via transcranial doppler ultrasound or phase contrast MRI (121) or in the small cerebral perforating arteries, using phase-contrast high resolution (7 Tesla) MRI (122).

\section{Cerebral Blood Flow Pulsatility}

Cerebral blood flow pulsatility can be measured at the level of the carotid artery via MRI and ultrasonography. High carotid artery blood flow pulsatility is associated with MRI features of cerebral small vessel disease (e.g., lacunes) and worse cognitive performance $(30,123)$. In large cerebral arteries, in cerebral perforating arteries and arterioles, flow pulsatility can be assessed by phase-contrast MRI. In this region, characterized by complex arterial network, 4D-flow MRI sequences (44), by measuring blood velocity in three orthogonal directions and in large volume, may be superior to standard (1D) PC-MRI. Indeed, since they do not require a specific measurement location or velocity encoding direction, 4D-flow MRI is free of angle-dependent 
TABLE 1 | Methods used to determine pressure and flow pulsatility in the macrovasculature.

\begin{tabular}{|c|c|c|c|c|}
\hline Method & Description & Variables & Advantages & Disadvantages \\
\hline MRI & High resolution imaging & $\begin{array}{l}\text { Arterial structure, blood flow } \\
\text { velocity }\end{array}$ & Very high-resolution & $\begin{array}{l}\text { Costly equipment, can only } \\
\text { be used in specialist } \\
\text { research or hospital settings }\end{array}$ \\
\hline $\begin{array}{l}\text { Ultrasound, high } \\
\text { resolution echotracking } \\
\text { methods }\end{array}$ & $\begin{array}{l}\text { Single micrometer resolution } \\
\text { during continuous } \\
\text { measurements }\end{array}$ & $\begin{array}{l}\text { Arterial structure, pulsatility } \\
\text { index }\end{array}$ & Mobile equipment available & Costly equipment \\
\hline $\begin{array}{l}\text { Applanation tonometry, } \\
\text { pulse wave velocity, } \\
\text { and analysis }\end{array}$ & $\begin{array}{l}\text { Pressure sensor placed on } \\
\text { palpable artery to record } \\
\text { arterial waveform } \\
\text { Proprietary algorithms used } \\
\text { to derive central BP } \\
\text { parameters }\end{array}$ & $\begin{array}{l}\text { Arterial stiffness, central } \\
\text { pulse pressure, augmented } \\
\text { pressure, augmentation } \\
\text { index }\end{array}$ & $\begin{array}{l}\text { Central PP and wave } \\
\text { parameters may give more } \\
\text { useful clinical information } \\
\text { that peripheral } \\
\text { measurements }\end{array}$ & $\begin{array}{l}\text { User dependent, results are } \\
\text { dependent on pressure } \\
\text { wave calibration method } \\
\text { and device (algorithm) }\end{array}$ \\
\hline $\begin{array}{l}\text { Oscillometric central } \\
\mathrm{BP}\end{array}$ & $\begin{array}{l}\text { BP cuff placed around the } \\
\text { upper arm, algorithms used } \\
\text { to determine central BP } \\
\text { Suprasystolic methods also } \\
\text { available }\end{array}$ & $\begin{array}{l}\text { Central pulse pressure, } \\
\text { augmented pressure, } \\
\text { augmentation index } \\
\text { (including possibility to } \\
\text { measure variables over } 24 \mathrm{~h} \text { ) }\end{array}$ & $\begin{array}{l}\text { Central pulse pressure and } \\
\text { wave parameters may give } \\
\text { more useful clinical } \\
\text { information that peripheral } \\
\text { measurements }\end{array}$ & $\begin{array}{l}\text { Can be highly dependent on } \\
\text { brachial BP measurement, } \\
\text { results are dependent on } \\
\text { pressure wave calibration } \\
\text { method and device } \\
\text { (algorithm) }\end{array}$ \\
\hline $\begin{array}{l}\text { Intra-arterial (invasive) } \\
\text { catheter methods }\end{array}$ & $\begin{array}{l}\text { Recordings taken during } \\
\text { invasive hospital } \\
\text { procedures, most } \\
\text { commonly coronary } \\
\text { angiography, or coronary } \\
\text { artery bypass grafting }\end{array}$ & $\begin{array}{l}\mathrm{BP} \text { and Doppler flow } \\
\text { velocity (if specialist } \\
\text { pressure-flow wires are } \\
\text { used) }\end{array}$ & $\begin{array}{l}\text { High-quality invasive } \\
\text { recordings }\end{array}$ & $\begin{array}{l}\text { Difficult and expensive to } \\
\text { collect the data, only } \\
\text { suitable in specific patient } \\
\text { populations }\end{array}$ \\
\hline
\end{tabular}

$B P$, blood pressure; $M R I$, magnetic resonance imaging.

errors (velocity errors ensuing from the misalignment between velocity encoding and blood velocity). Another key result of encoding in three directions is the possibility to quantify complex flow patterns, which are related to local dilation $(31,35,124,125)$ and arterial wall disruption (126).

\section{Cerebral Microvascular Perfusion}

Intravoxel incoherent motion MRI, a diffusion-weighted MRI technique without the use of contrast agents, can be used to assess cerebral microvascular perfusion (127). This technique enables assessment of both the parenchyma and microvasculature and is based on the diffusion of water molecules in parenchyma and incoherent motion of water molecules in the microvasculature (127). Intravoxel incoherent motion MRI has been used mainly to investigate the brain, but may also be used in other parts of the body (128). Although it was introduced in the mideighties (129) it is still experimental, but it can provide a high signal-to-noise ratio and high spatial resolution $(127,128)$. An advantage of this technique is the simultaneous assessment of tissue microstructure and microvasculature, and, therefore, of the interplay between brain tissue and vessels (130).

Higher cerebral pulsatility index has been shown to be associated with MRI features of cerebral small vessel disease (131) and cognitive impairment (132). Furthermore, a recent study using intravoxel incoherent motion MRI found that the microvascular properties of the hippocampus are altered in individuals with T2D (130), which may be related to worse cognitive function. While these biomarkers show promise for identifying individuals at elevated risk, their prognostic value needs to be confirmed in larger prospective studies. Cerebral vasoreactivity of small arteries/arterioles using 7 Tesla provides a direct functional measurement of the cerebral microvasculature and may be preferable for investigating the interaction between the macro- and microvasculature, but this technology is available only in few, specialized centers, and only proof-of concept studies have been performed.

\section{The Kidney}

Renal hemodynamics are classically assessed by renal plasma flow, which is an invasive and time-consuming technique, including radiotracer intravenous administration (133, 134). More recently, non-invasive techniques, including ultrasound and MRI have been successfully applied (135) allowing a direct quantification of renal microvascular blood flow, together with structural characterization.

\section{Magnetic Resonance Imaging}

Without the use of radiation, MRI allows for blood flow and velocity assessment via phase-contrast sequences and it 
TABLE 2 | Methods used to determine pressure and flow pulsatility in the microvasculature.

\begin{tabular}{|c|c|c|c|c|}
\hline Method & Description & Variables & Advantages & Disadvantages \\
\hline \multicolumn{5}{|l|}{ Brain } \\
\hline Cerebral vasoreactivity & $\begin{array}{l}\text { Vasodilatory ability of the } \\
\text { cerebral (micro)vasculature }\end{array}$ & $\begin{array}{l}\text { Mean increase in blood flow } \\
\text { or blood flow velocity after } \\
\text { stimulation with either } \\
\text { acetazolamide or } \mathrm{CO}_{2}\end{array}$ & $\begin{array}{l}\text { Functional imaging; also } \\
\text { possible at the level of the } \\
\text { microvasculature with } 7 \\
\text { Tesla MRI }\end{array}$ & $\begin{array}{l}\text { Most methods available measure vasoreactivity } \\
\text { at the level of large intracranial arteries, and not } \\
\text { directly at the level of the microvasculature }\end{array}$ \\
\hline $\begin{array}{l}\text { Cerebral blood flow } \\
\text { pulsatility }\end{array}$ & Blood flow pulsatility & Pulsatility index & $\begin{array}{l}\text { Functional imaging; also } \\
\text { possible at the level of the } \\
\text { microvasculature with } \\
\text { phase-contrast } 7 \text { Tesla MRI }\end{array}$ & $\begin{array}{l}\text { Most methods available measure vasoreactivity } \\
\text { at the level of large intracranial arteries, and not } \\
\text { directly at the level of the microvasculature }\end{array}$ \\
\hline $\begin{array}{l}\text { Cerebral microvascular } \\
\text { perfusion }\end{array}$ & $\begin{array}{l}\text { Intravoxel incoherent motion } \\
\text { MRI, a diffusion-weighted } \\
\text { MRI technique without the } \\
\text { use of contrast agents }\end{array}$ & $\begin{array}{l}\text { Perfusion fraction, a } \\
\text { measure for blood perfusion } \\
\text { volume; and blood flow } \\
\text { These variables are } \\
\text { potentially sensitive to } \\
\text { microvascular pathology }\end{array}$ & $\begin{array}{l}\text { High signal-to-noise ratio } \\
\text { and high spatial resolution; } \\
\text { simultaneous assessment of } \\
\text { tissue microstructure and } \\
\text { microvasculature }\end{array}$ & Experimental tool \\
\hline \multicolumn{5}{|l|}{ Kidney } \\
\hline MRI & High resolution imaging & $\begin{array}{l}\text { Arterial structure and blood } \\
\text { flow velocity, vascular } \\
\text { resistance, pulsatility index }\end{array}$ & Very high-resolution & $\begin{array}{l}\text { Costly equipment, can only be used in } \\
\text { specialist research or hospital settings }\end{array}$ \\
\hline $\begin{array}{l}\text { Renal Doppler } \\
\text { sonography }\end{array}$ & $\begin{array}{l}\text { Employs Doppler effect to } \\
\text { analyze renal blood flow } \\
\text { velocity pattern }\end{array}$ & $\begin{array}{l}\text { Resistive index, pulsatility } \\
\text { index, compliance index, } \\
\text { renal acceleration time }\end{array}$ & $\begin{array}{l}\text { Non-invasive technique; } \\
\text { cost-effectiveness }\end{array}$ & Highly operator-dependent \\
\hline $\begin{array}{l}\text { Transesophageal } \\
\text { Doppler }\end{array}$ & $\begin{array}{l}\text { Employs Doppler effect to } \\
\text { analyze renal blood flow } \\
\text { velocity pattern }\end{array}$ & $\begin{array}{l}\text { Resistive index, pulsatility } \\
\text { index }\end{array}$ & Real-time measurement & Invasive procedure, specific training is needed \\
\hline \multicolumn{5}{|l|}{ Retina } \\
\hline $\begin{array}{l}\text { Fluorescein } \\
\text { angiography and } \\
\text { indocyanine green } \\
\text { angiography }\end{array}$ & $\begin{array}{l}\text { Calculates the time of } \\
\text { transition of a dye molecule } \\
\text { throughout a microvascular } \\
\text { segment }\end{array}$ & $\begin{array}{l}\text { Vessel diameter } \\
\text { (photo/video/mean transit } \\
\text { time two-point } \\
\text { fluorophotometry), mean } \\
\text { transit time, arteriovenous } \\
\text { passage }\end{array}$ & $\begin{array}{l}\text { Coupled with Scanner laser } \\
\text { ophthalmoscopy allows the } \\
\text { direct measurement of } \\
\text { retinal blood flow }\end{array}$ & $\begin{array}{l}\text { Reliable data only if the vascular segment, } \\
\text { diameter and volume of distribution satisfy } \\
\text { specific conditions }\end{array}$ \\
\hline $\begin{array}{l}\text { Laser Doppler } \\
\text { velocimetry }\end{array}$ & $\begin{array}{l}\text { Measure of the maximum } \\
\text { blood cell velocity in retinal } \\
\text { vessels through the analysis } \\
\text { of Doppler shifts }\end{array}$ & $\begin{array}{l}\text { Blood velocity Estimated } \\
\text { volumetric flow (based on } \\
\text { the diameter of vessels } \\
>50 \mu \mathrm{m} \text { ) }\end{array}$ & $\begin{array}{l}\text { Useful to document } \\
\text { physiologic changes in } \\
\text { retinal perfusion }\end{array}$ & $\begin{array}{l}\text { Very complex technique with multiple controls } \\
\text { to manipulate, which makes it available only in } \\
\text { research settings }\end{array}$ \\
\hline $\begin{array}{l}\text { Laser Doppler } \\
\text { flowmetry }\end{array}$ & $\begin{array}{l}\text { Using spectral analysis and } \\
\text { wavelet transform }\end{array}$ & $\begin{array}{l}\text { Blood flow velocity, } \\
\text { pulsatility }\end{array}$ & $\begin{array}{l}\text { Blood flow measurement is } \\
\text { derived from red blood cells } \\
\text { velocity and volume instead } \\
\text { of diameter, thereby } \\
\text { minimizing the variability due } \\
\text { to different imaging methods } \\
\text { for diameter calculation }\end{array}$ & $\begin{array}{l}\text { Individual anatomy and local hematocrit may } \\
\text { alter the blood flow estimation, a comparison } \\
\text { between healthy and pathologic retina may be } \\
\text { difficult }\end{array}$ \\
\hline $\begin{array}{l}\text { Scanning laser Doppler } \\
\text { flowmetry }\end{array}$ & $\begin{array}{l}\text { Integration of spectral } \\
\text { analysis and red blood cell } \\
\text { flow }\end{array}$ & $\begin{array}{l}\text { Arterial structure, blood flow } \\
\text { velocity }\end{array}$ & $\begin{array}{l}\text { Non-invasive, in-vivo, both } \\
\text { morphological and } \\
\text { functional analysis }\end{array}$ & $\begin{array}{l}\text { Mixed signal of retinal and choroidal tissue, } \\
\text { limiting the interpretation of results, only } \\
\text { available in research settings }\end{array}$ \\
\hline $\begin{array}{l}\text { Laser speckle } \\
\text { flowgraphy }\end{array}$ & $\begin{array}{l}\text { Measure of the blood flow } \\
\text { based on the laser speckle } \\
\text { phenomenon and mean blur } \\
\text { rate pulse waveform } \\
\text { analysis }\end{array}$ & $\begin{array}{l}\text { Blood flow velocity, blowout } \\
\text { time, blowout score }\end{array}$ & $\begin{array}{l}\text { Quantitative ocular blood } \\
\text { flow measurement in vivo }\end{array}$ & $\begin{array}{l}\text { Arbitrary units implying difficult comparison with } \\
\text { other techniques, subject compliance (good } \\
\text { fixation) to obtain good images }\end{array}$ \\
\hline $\begin{array}{l}\text { Doppler optical } \\
\text { computed tomography }\end{array}$ & $\begin{array}{l}\text { Motion-contrast imaging } \\
\text { based on backscattered } \\
\text { light from retinal tissue } \\
\text { High-resolution } \\
\text { cross-sectional imaging }\end{array}$ & $\begin{array}{l}\text { Arterial structure and } \\
\text { anatomy, blood flow } \\
\text { extracted from Doppler shift }\end{array}$ & Contactless and dye-free & $\begin{array}{l}\text { Costly equipment, can only be used in } \\
\text { specialist research or hospital setting, cannot } \\
\text { be applied for in vivo real-time measurements, } \\
\text { motion-sample dependent }\end{array}$ \\
\hline Color Doppler & $\begin{array}{l}\text { Quantification of blood } \\
\text { velocities through Doppler } \\
\text { effect }\end{array}$ & $\begin{array}{l}\text { Resistive index, blood flow } \\
\text { velocity }\end{array}$ & $\begin{array}{l}\text { Ocular blood flow and blood } \\
\text { velocity easily uncoupled }\end{array}$ & $\begin{array}{l}\text { An increase in intraocular pressure may occur } \\
\text { when the probe is applied on the closed eye, } \\
\text { poor reproducibility }\end{array}$ \\
\hline
\end{tabular}

MRl, magnetic resonance imaging. 
can provide detailed 3D angiography. As such, MRI can quantify vascular resistance measures and pulsatility index (136). Moreover, blood oxygen level dependent MRI sequences allow for the measurement of kidney tissue hypoxia.

\section{Renal Doppler Sonography}

The most widely used technique for blood velocity assessment is Doppler ultrasound due to wide availability, non-invasive, and relatively easy use. Duplex ultrasound on the interlobar renal arteries allows for the measurement of a number of variables expressing flow pulsatility and vascular resistance, among which the most widely used is renal resistive index-RIan angle-independent, semiquantitative parameter defined as [peak systolic velocity (PSV)-end diastolic velocity(EDV)]/PSV. The clinical significance of RI is still a matter of debate, since it may be determined by systemic hemodynamics, arterial compliance, PWV (137-139) or local flow pulsatility, rather than renal vascular resistance (140). However, this observation, which is usually seen as a limitation of the technique, might indeed make RI a good candidate to represent the interaction between the macro- and microvasculature, or rather its integrated effect on the kidney. Finally, RI is able to track drug-induced changes in renal hemodynamics (141). This led to the calculation of a dynamic RI, estimating renal vasodilatory capacity before and 5 min after nitrate-induced vasodilation (Figure 3).

\section{Transesophageal Doppler}

A reduced systemic pulsatile blood flow is considered to hamper renal perfusion leading to acute kidney failure.

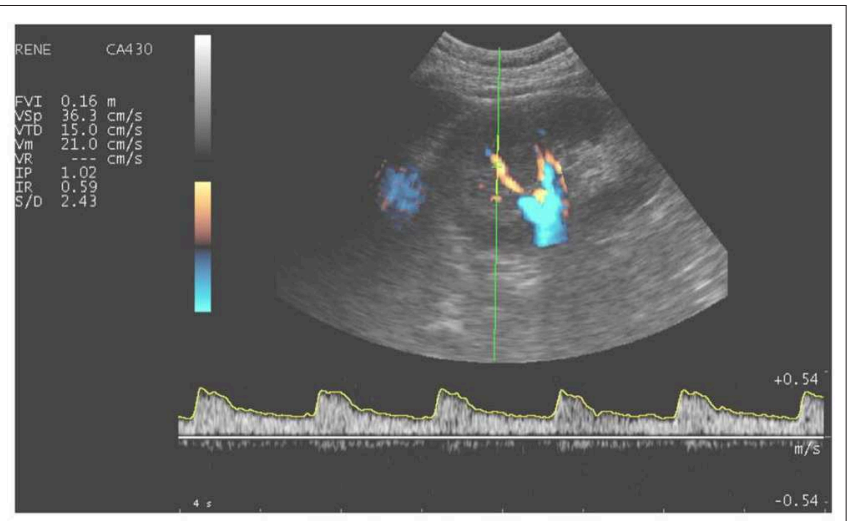

Renal resistive index $(\mathrm{RI})$

peak systolic velocity- end diastolic velocity

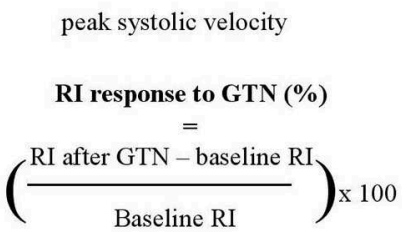

FIGURE 3 | An example of renal Doppler sonography. A number of variables expressing flow pulsatility and vascular resistance can be determined, including renal resistive index (RI) and dynamic RI.
Transesophageal Doppler allows the measurement of angledependent blood flow velocities (PSV, EDV, and mean diastolic velocity) and angle -independent indices (RI and pulsatile index) in the renal artery. Despite being an invasive procedure, the measurement can be done in real-time and images can be obtained in $<5 \mathrm{~min}$ by trained personnel [summarized in (142)].

To date, a number of studies have demonstrated the prognostic role of RI, especially in T2D (143) and chronic kidney disease (144), whereas dynamic RI is associated with PWV and predicts microalbuminuria development in patients with hypertension and T2D (138, 145). Thus, at present, these measures may be useful renal biomarkers to investigate the interaction between the macro- and microvasculature. To our knowledge, the relationship between markers of renal pulsatility obtained using MRI and clinical outcomes has never been assessed, though this technique is promising and likely more accurate and reproducible than ultrasoundbased ones.

\section{The Retina}

Most widely used retinal microvascular variables include the central retinal arteriolar/venular diameters or equivalents (146), although more recent techniques allow a near-histological evaluation of the arteriolar wall (9). Recently, other measures of the retinal microvascular network geometry have been studied, e.g., tortuosity, bifurcation angles and optimality, and fractal dimensions (146), which are associated with diabetic retinopathy, stroke, and cognitive impairment (147). It is also possible to dynamically assess the retinal microvasculature via endothelium-dependent vasodilatory responses [in terms of perfusion and diameter changes, to flicker light $(146,148)]$.

\section{Angiographic Techniques}

Angiographic methods involve the measurement of transit time of a contrast agent from arteries to veins, which is inversely correlated with blood flow $(149,150)$. Limitations to this technique are related to diabetes (the sum of all vessel diameters might not be directly related to retinal blood volume) and vasodilation (which alters the contrast distribution volume with an increased circulation time but no changes in blood flow) $(149,150)$. These measures, made through a scanner laser ophthalmoscopy (SLO) require injection of a contrast agent $(151,152)$. SLO coupled with adaptive optics (153) and optical coherence tomography angiography (OCT-A) allow for the measurement of all the retinal layers and accurately visualize both retinal and choroidal microvasculature without contrast agent injection $(154,155)$.

\section{Laser Doppler Techniques}

Laser Doppler techniques are based on the optical Doppler effect, which relies on the reflection of a high coherence laser beam scattered in vivo on vascular tissue and captures the shift of the underlying moving red blood cells. The backscattered light gives a measure of both the incident light 
(vessel wall) as well as the shifted light (red blood cells), thus providing a measure of relative blood flow, blood volume, and blood velocity within a specified region of the retina. An absolute red blood cell velocity is obtainable by means of bidirectional laser Doppler velocimetry, when the light scattered from the erythrocytes is detected from two directions. For the volumetric blood flow rate calculation, an accurate measure of the diameter is required (156). Laser Doppler flowmetry does not rely on vessel diameter measurement but is based on the intensity of signal derived from the red blood cell volume and velocity (157). Combining the laser Doppler flowmetry with laser scanning tomography, a twodimensional mapping of retinal blood flow can be obtained, resulting from blood flow measurements based on both single and multiple scattering events from many red blood cells. Local frequency components of the reflected light are obtained at each scanning point and combined with blood velocity (158).

\section{Other Doppler Techniques}

Combining OCT with the Doppler technique, a simultaneous measure of blood flow and vascular structure and anatomy can be obtained (159). Applied to retrobulbar vessels, color Doppler provides a measurement of PSV and EDV from which RI and pulsatility index can be obtained. Recently, a novel technique has been developed, laser Doppler holography (Figure 4), which overcomes limits of low temporal resolution using previous techniques such OCT-A, allowing a fullfield spatio-temporal filtered characterization of retinal small arteries (160).

\section{Laser Speckle Flowgraphy}

Laser speckle flowgraphy is based on an interference phenomenon resulting in a laser speckle pattern changing when a scattered sample moves and allows the measurement of human retinal blood flow in a semi-quantitative fashion.
It calculates the pulsatile flow from the difference in the mean blur rate produced by the moving erythrocytes during the systolic and diastolic phase (blowout time and acceleration time index). The blowout time has been inversely associated with age, brachial-ankle PWV and directly correlated with carotid IMT. Studies in healthy subjects observed a correlation between pulsatile flow with carotid artery thickening and high carotid plaque formation (161).

Despite a number of studies examining the relationship between microvascular structural changes at the retinal level and systemic macrovascular disease (162-165), the prognostic value of retinal pulsatility variables remains to be fully elucidated. One recent study showed that impaired retinal microvascular function predicted all-cause mortality in patients with end stage renal disease (148). Given that laser Doppler techniques are the only currently available methods to measure retinal pulsatility, they hold most promise for investigating the interaction between the macroand microvasculature.

\section{SUMMARY AND CONCLUSION}

Over the last few decades, arterial stiffness has emerged as a major, independent CVD risk factor. There is now ample evidence that arterial stiffening gives rise to increased pressure and flow pulsatility which may be transmitted to the microvasculature and contribute to target organ damage in the brain, kidney, and eye. In this review we have provided a comprehensive summary of the methods to measure the interaction between the macro- and microvasculature. Further understanding the relationship between the macroand microvasculature and target organs will provide avenues for future treatment and management strategies that can reduce the impact of pulsatility and minimize damage to target organs, lessen the burden of associated disease and
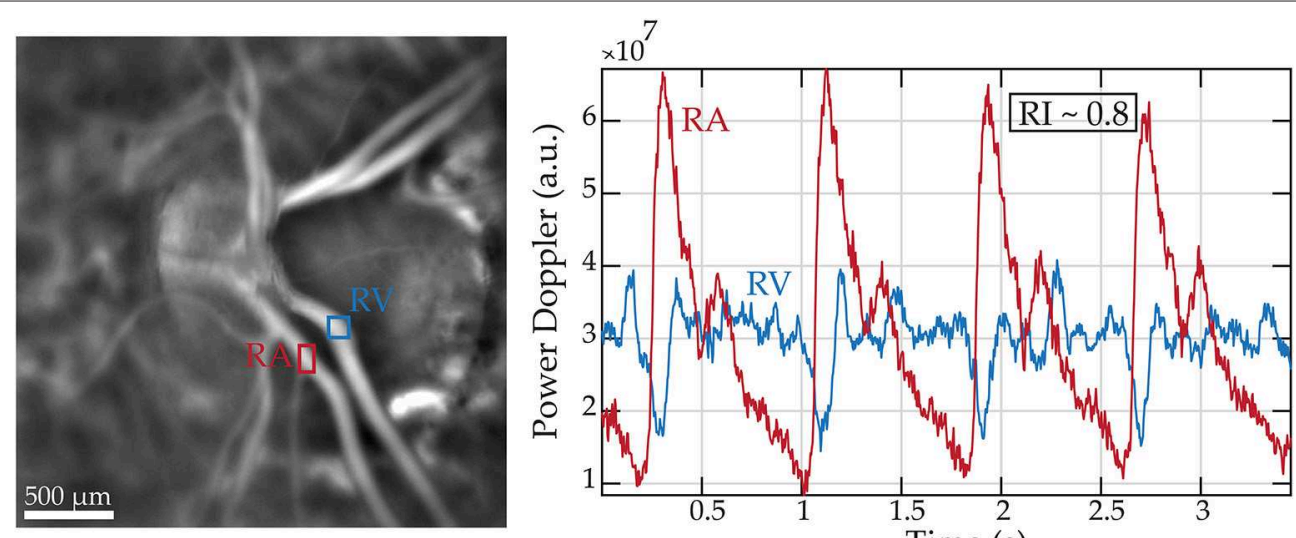

Time (s)

FIGURE 4 | Retinal blood flow measurements in a healthy subject using laser Doppler holography. Left panel: Power Doppler image revealing the vascularized structures. Two regions of interest (ROI) marking a retinal artery and vein are drawn in red and blue, respectively. Right panel: Variations of blood flow over cardiac cycles in the regions of interest. 
ultimately improve survival. Future work should determine whether both lifestyle and pharmacological interventions can regress accelerated arterial stiffening and whether this in turn leads to a reduction in pressure and flow pulsatility and target organ damage.

\section{AUTHOR CONTRIBUTIONS}

$\mathrm{RC}$ and $\mathrm{RB}$ contributed conception and design of the study. All authors wrote sections of the manuscript,

\section{REFERENCES}

1. Lim SS, Vos T, Flaxman AD, Danaei G, Shibuya K, Adair-Rohani H, et al. A comparative risk assessment of burden of disease and injury attributable to 67 risk factors and risk factor clusters in 21 regions, 1990-2010: a systematic analysis for the Global Burden of Disease Study 2010. Lancet. (2012) 380:2224-60. doi: 10.1016/S0140-6736(12)61766-8

2. World Health Organization. A Global Brief On Hypertension. Genva: World Heath Organization (2013).

3. World Health Organization. Cardiovascular Diseases. Geneva: World Health Organization (2017).

4. Laurent S, Hayoz D, Trazzi S, Boutouyrie P, Waeber B, Omboni $\mathrm{S}$, et al. Isobaric compliance of the radial artery is increased in patients with essential hypertension. J Hypertens. (1993) 11:89-98. doi: 10.1097/00004872-199301000-00013

5. Benetos A, Laurent S, Hoeks A, Boutouyrie P, Safar M. Arterial alterations with aging and high blood pressure. A noninvasive study of carotid and femoral arteries. Arterioscler Thromb. (1993) 13:90-7. doi: 10.1161/01.ATV.13.1.90

6. Laurent S, Girerd X, Mourad J-J, Lacolley P, Beck L, Boutouyrie P, et al. Elastic modulus of the radial artery wall material is not increased in patients with essential hypertension. Arterioscler Thromb. (1994) 14:122331. doi: 10.1161/01.ATV.14.7.1223

7. Boutouyrie P, Bussy C, Lacolley P, Girerd X, Laloux B, Laurent S. Association between local pulse pressure, mean blood pressure, and large-artery remodeling. Circulation. (1999) 100:1387-93. doi: 10.1161/01.CIR.100.13.1387

8. Humphrey JD, Harrison DG, Figueroa CA, Lacolley P, Laurent S. Central artery stiffness in hypertension and aging: a problem with cause and consequence. Circ Res. (2016) 118:379-81. doi: 10.1161/CIRCRESAHA.115.307722

9. Rosenbaum D, Mattina A, Koch E, Rossant F, Gallo A, Kachenoura N, et al. Effects of age, blood pressure and antihypertensive treatments on retinal arterioles remodeling assessed by adaptive optics. J Hypertens. (2016) 34:1115-22. doi: 10.1097/HJH.0000000000000894

10. Schiffrin EL. Reactivity of small blood vessels in hypertension: relation with structural changes. State of the art lecture. Hypertension. (1992) 19(Suppl. 2):II1-9. doi: 10.1161/01.HYP.19.2_Suppl.II1-a

11. Rizzoni D, Agabiti-Rosei E. Structural abnormalities of small resistance arteries in essential hypertension. Intern Emerg Med. (2012) 7:205-12. doi: 10.1007/s11739-011-0548-0

12. Heagerty AM, Izzard AS. Small-artery changes in hypertension. J Hypertens. (1995) 13:1560-5. doi: 10.1097/00004872-19951201000008

13. McEniery CM, Yasmin, Hall IR, Qasem A, Wilkinson IB, Cockcroft JR. Normal vascular aging: differential effects on wave reflection and aortic pulse wave velocity: the Anglo-Cardiff Collaborative Trial (ACCT). J Am Coll Cardiol. (2005) 46:1753-60. doi: 10.1016/j.jacc.2005.07.037

14. Vermeersch S. Reference values for arterial stiffness' collaboration. Determinants of pulse wave velocity in healthy people and in the presence of cardiovascular risk factors: Establishing normal and reference values. Eur Heart J. (2010) 31:2338-50. doi: 10.1093/eurheartj/ehq165 contributed to manuscript revision, read and approved the submitted version.

\section{FUNDING}

Work on this manuscript was made possible for RC by a Prestige and Marie Curie Fellowship. TS was supported by a L'Institute Servier research grant. DP was supported by a Broadreach Postdoctoral Fellowship. AG received funding from the European Union Seventh Framework Programme (267128).

15. Franklin SS. Arterial stiffness and hypertension. Hypertension. (2005) 45:349-51. doi: 10.1161/01.HYP.0000157819.31611.87

16. Stehouwer C, Henry R, Ferreira I. Arterial stiffness in diabetes and the metabolic syndrome: a pathway to cardiovascular disease. Diabetologia. (2008) 51:527-39. doi: 10.1007/s00125-007-0918-3

17. Mitchell GF. Effects of central arterial aging on the structure and function of the peripheral vasculature: implications for end-organ damage. J Appl Physiol. (2008) 105:1652-60. doi: 10.1152/japplphysiol.90549.2008

18. Laurent S, Boutouyrie P. The structural factor of hypertension. Circ Res. (2015) 116:1007-21. doi: 10.1161/CIRCRESAHA.116.303596

19. Leoncini G, Ratto E, Viazzi F, Vaccaro V, Parodi A, Falqui V, et al. Increased ambulatory arterial stiffness index is associated with target organ damage in primary hypertension. Hypertension. (2006) 48:397-403. doi: 10.1161/01.HYP.0000236599.91051.1e

20. Gómez-Marcos MÁ, Recio-Rodríguez JI, Patino-Alonso MC, GómezSánchez L, Agudo-Conde C, Gómez-Sánchez M, et al. Ambulatory arterial stiffness indices and target organ damage in hypertension. BMC Cardiovasc Disord. (2012) 12:1. doi: 10.1186/1471-2261-12-1

21. Katsi V, Vlachopoulos C, Souretis G, Baou K, Dagalaki I, Alexopoulos $\mathrm{N}$, et al. Association between retinal microcirculation and aortic stiffness in hypertensive patients. Int J Cardiol. (2012) 157:370-3. doi: 10.1016/j.ijcard.2010.12.074

22. Triantafyllidi H, Tzortzis S, Lekakis J, Ikonomidis I, Arvaniti C, Trivilou $\mathrm{P}$, et al. Association of target organ damage with three arterial stiffness indexes according to blood pressure dipping status in untreated hypertensive patients. Am J Hypertens. (2010) 23:1265-72. doi: 10.1038/ajh.2010.156

23. Bruno RM, Cartoni G, Stea F, Armenia S, Bianchini E, Buralli S, et al. Carotid and aortic stiffness in essential hypertension and their relation with target organ damage: the CATOD study. J Hypertens. (2017) 35:310-18. doi: 10.1097/HJH.0000000000001167

24. Climie RE, Srikanth V, Keith LJ, Davies JE, Sharman JE. Exercise excess pressure and exercise-induced albuminuria in patients with type 2 diabetes mellitus. Am J Physiol Heart Circ Physiol. (2015) 308:H1136-42. doi: 10.1152/ajpheart.00739.2014

25. Climie RE, Picone DS, Blackwood S, Keel SE, Qasem A, Rattigan S, et al. Pulsatile interaction between the macro-vasculature and micro-vasculature: proof-of-concept among patients with type 2 diabetes. Eur J Appl Physiol. (2018) 118:2455. doi: 10.1007/s00421-018-3972-2

26. Lockhart CJ, McCann A, Pinnock R, Hamilton P, Harbinson M, McVeigh GE. Multimodal functional and anatomic imaging identifies preclinical microvascular abnormalities in type 1 diabetes mellitus. Am J Physiol Heart Circ Physiol. (2014) 307:H1729-36. doi: 10.1152/ajpheart.00372.2014

27. Urbančič-Rovan V, Bernjak A, Stefanovska A, AŽman-Juvan K, Kocijančič A. Macro-and microcirculation in the lower extremitiespossible relationship. Diabetes Res Clin Pract. (2006) 73:166-73. doi: 10.1016/j.diabres.2006.01.002

28. Westerhof N, Sipkema P, Bos GVD, Elzinga G. Forward and backward waves in the arterial system. Cardiovasc Res. (1972) 6:648-56. doi: $10.1093 / \mathrm{cvr} / 6.6 .648$

29. Nichols WW, O'Rourke MF, Vlachopoulos C. McDonald's Blood Flow in Arteries; Theoretical, Experimental and Clinical Principles. 6th ed. Florida, FL: Hodder Arnold (2011). 
30. Mitchell GF, van Buchem MA, Sigurdsson S, Gotal JD, Jonsdottir MK, Kjartansson Ó, et al. Arterial stiffness, pressure and flow pulsatility and brain structure and function: the Age, Gene/Environment SusceptibilityReykjavik study. Brain. (2011) 134:3398-407. doi: 10.1093/brain/awr253

31. Guala A, Teixidó-Tura G, Rodríguez-Palomares J, Ruiz-Muñoz A, DuxSantoy L, Villalva N, et al. Proximal aorta longitudinal strain predicts aortic root dilation rate and aortic events in Marfan syndrome. Eur Heart J. (2019) 40:2047-55. doi: 10.1093/eurheartj/ehz191

32. Leung D, Glagov S, Mathews MB. Cyclic stretching stimulates synthesis of matrix components by arterial smooth muscle cells in vitro. Science. (1976) 191:475-7. doi: 10.1126/science. 128820

33. Lehoux S, Tedgui A. Cellular mechanics and gene expression in blood vessels. J Biomech. (2003) 36:631-43. doi: 10.1016/S0021-9290(02)00441-4

34. Guala A, Camporeale C, Ridolfi L. Compensatory effect between aortic stiffening and remodelling during ageing. PLoS ONE. (2015) 10:e0139211. doi: 10.1371/journal.pone.0139211

35. Guala A, Rodriguez-Palomares J, Dux-Santoy L, Teixido-Tura G, Maldonado $\mathrm{G}$, Galian L, et al. Influence of aortic dilation on the regional aortic stiffness of bicuspid aortic valve assessed by 4 -dimensional flow cardiac magnetic resonance: comparison with Marfan syndrome and degenerative aortic aneurysm. JACC Cardiovasc Imaging. (2019) 12:1020-9. doi: 10.1016/j.jcmg.2018.03.017

36. Erbel R, Aboyans V, Boileau C, Bossone E, Bartolomeo RD, Eggebrecht H, et al. 2014 ESC Guidelines on the diagnosis and treatment of aortic diseases: document covering acute and chronic aortic diseases of the thoracic and abdominal aorta of the adult the task force for the diagnosis and treatment of aortic diseases of the European Society of Cardiology (ESC). Eur Heart J. (2014) 35:2873-926. doi: 10.1093/eurheartj/ehu281

37. Pase MP, Beiser A, Himali JJ, Tsao C, Satizabal CL, Vasan RS, et al. Aortic stiffness and the risk of incident mild cognitive impairment and dementia. Stroke. (2016) 47:2256-61. doi: 10.1161/STROKEAHA.116.013508

38. Meyer ML, Palta P, Tanaka H, Deal JA, Wright J, Knopman DS, et al. Association of central arterial stiffness and pressure pulsatility with mild cognitive impairment and dementia: the Atherosclerosis Risk in Communities Study-Neurocognitive Study (ARIC-NCS). J Alzheimer's Dis. (2017) 57:195-204. doi: 10.3233/JAD-161041

39. Palta P, Sharrett AR, Wei J, Meyer ML, Kucharska-Newton A, Power MC, et al. Central arterial stiffness is associated with structural brain damage and poorer cognitive performance: the ARIC study. J Am Heart Assoc. (2019) 8:e011045. doi: 10.1161/JAHA.118.011045

40. Tarumi T, Khan MA, Liu J, Tseng BM, Parker R, Riley J, et al. Cerebral hemodynamics in normal aging: central artery stiffness, wave reflection, and pressure pulsatility. J Cereb Blood Flow Metab. (2014) 34:971-8. doi: $10.1038 / \mathrm{jcbfm} .2014 .44$

41. Xu T-Y, Staessen JA, Wei F-F, Xu J, Li F-H, Fan W-X, et al. Blood flow pattern in the middle cerebral artery in relation to indices of arterial stiffness in the systemic circulation. Am J Hypertens. (2012) 25:319-24. doi: 10.1038/ajh.2011.223

42. Wardlaw JM, Smith EE, Biessels GJ, Cordonnier C, Fazekas F, Frayne R, et al. Neuroimaging standards for research into small vessel disease and its contribution to ageing and neurodegeneration. Lancet Neurol. (2013) 12:822-38. doi: 10.1016/S1474-4422(13)70124-8

43. Tsao CW, Himali JJ, Beiser AS, Larson MG, DeCarli C, Vasan RS, et al. Association of arterial stiffness with progression of subclinical brain and cognitive disease. Neurology. (2016) 86:619-26. doi: 10.1212/WNL.0000000000002368

44. Rivera-Rivera LA, Turski P, Johnson KM, Hoffman C, Berman SE, Kilgas P, et al. 4D flow MRI for intracranial hemodynamics assessment in Alzheimer's disease. J Cereb Blood Flow Metab. (2016) 36:1718-30. doi: 10.1177/0271678X15617171

45. Climie RE, Srikanth V, Beare R, Keith LJ, Fell J, Davies JE, et al. Aortic reservoir characteristics and brain structure in people with type 2 diabetes mellitus; a cross sectional study. Cardiovasc Diabetol. (2014) 13:143. doi: 10.1186/s12933-014-0143-6

46. Georgianos PI, Sarafidis PA, Liakopoulos V. Arterial stiffness: a novel risk factor for kidney injury progression? Am J Hypertens. (2015) 28:958-65. doi: 10.1093/ajh/hpv004
47. Bouchi R, Babazono T, Mugishima M, Yoshida N, Nyumura I, Toya K, et al. Arterial stiffness is associated with incident albuminuria and decreased glomerular filtration rate in type 2 diabetic patients. Diabetes Care. (2011) 34:2570-5. doi: 10.2337/dc11-1020

48. Sheen Y-J, Lin J-L, Li T-C, Bau C-T, Sheu WH-H. Peripheral arterial stiffness is independently associated with a rapid decline in estimated glomerular filtration rate in patients with type 2 diabetes. BioMed Res Int. (2013) 2013:309294. doi: 10.1155/2013/309294

49. Liu C-S, Pi-Sunyer FX, Li C-I, Davidson LE, Li T-C, Chen W, et al. Albuminuria is strongly associated with arterial stiffness, especially in diabetic or hypertensive subjects - a population-based study (Taichung Community Health Study, TCHS). Atherosclerosis. (2010) 211:315-21. doi: 10.1016/j.atherosclerosis.2010.02.015

50. Madero M, Peralta C, Katz R, Fried L, Najjar S, Shlipak M, et al. Association of arterial rigidity with incident kidney disease and kidney function decline: the health ABC study. Clin J Am Soc Nephrol. (2013) 8:424-33. doi: 10.2215/CJN.07900812

51. Tomiyama H, Tanaka H, Hashimoto H, Matsumoto C, Odaira M, Yamada J, et al. Arterial stiffness and declines in individuals with normal renal function/early chronic kidney disease. Atherosclerosis. (2010) 212:345-50. doi: 10.1016/j.atherosclerosis.2010.05.033

52. Kim CS, Kim HY, Kang YU, Choi JS, Bae EH, Ma SK, et al. Association of pulse wave velocity and pulse pressure with decline in kidney function. J Clin Hypertens. (2014) 16:372-7. doi: 10.1111/jch.12302

53. Upadhyay A, Hwang S-J, Mitchell GF, Vasan RS, Vita JA, Stantchev PI, et al. Arterial stiffness in mild-to-moderate CKD. J Am Soc Nephrol. (2009) 20:2044-53. doi: 10.1681/ASN.2009010074

54. Woodard T, Sigurdsson S, Gotal JD, Torjesen AA, Inker LA, Aspelund T, et al. Mediation analysis of aortic stiffness and renal microvascular function. J Am Soc Nephrol. (2015) 26:1181-7. doi: 10.1681/ASN.2014050450

55. Penno G, Solini A, Orsi E, Bonora E, Fondelli C, Trevisan R, et al. Non-albuminuric renal impairment is a strong predictor of mortality in individuals with type 2 diabetes: the Renal Insufficiency And Cardiovascular Events (RIACE) Italian multicentre study. Diabetologia. (2018) 61:2277-89. doi: 10.1007/s00125-018-4691-2

56. Saint-Geniez M, D'Amore PA. Development and pathology of the hyaloid, choroidal and retinal vasculature. Int J Dev Biol. (2004) 48:1045-58. doi: 10.1387/ijdb.041895ms

57. Adler FH HW. Adler's Physiology of the Eye: Clinical Application. St. Louis: Mosby Year Book (1992).

58. Zhang X, Lim SC, Tavintharan S, Yeoh LY, Sum CF, Ang K, et al. Association of central arterial stiffness with the presence and severity of diabetic retinopathy in Asians with type 2 diabetes. Diab Vasc Dis Res. (2019) 16:498-505. doi: 10.1177/1479164119845904

59. Sato E, Feke GT, Appelbaum EY, Menke MN, Trempe CL, McMeel JW. Association between systemic arterial stiffness and age-related macular degeneration. Graefes Arch Clin Exp Ophthalmol. (2006) 244:963-71. doi: 10.1007/s00417-005-0201-6

60. Aissopou EK, Argyris AA, Nasothimiou EG, Konstantonis GD, Tampakis K, Tentolouris N, et al. Ambulatory aortic stiffness is associated with narrow retinal arteriolar caliber in hypertensives: the SAFAR study. Am J Hypertens. (2015) 29:626-33. doi: 10.1093/ajh/hpv145

61. Liu M, Wake M, Wong TY, He M, Xiao Y, Burgner D, et al. Associations of retinal microvascular caliber with intermediate phenotypes of large arterial function and structure: a systematic review and meta-analysis. Microcirculation. (2019) 26:e12557. doi: 10.1111/micc.12557

62. Harazny JM, Ott C, Raff U, Welzenbach J, Kwella N, Michelson G, et al. First experience in analysing pulsatile retinal capillary flow and arteriolar structural parameters measured noninvasively in hypertensive patients. $J$ Hypertens. (2014) 32:2246-52. doi: 10.1097/HJH.0000000000000308

63. Kotliar KE, Baumann M, Vilser W, Lanzl IM. Pulse wave velocity in retinal arteries of healthy volunteers. Br J Ophthalmol. (2011) 95:675-9. doi: 10.1136/bjo.2010.181263

64. Kotliar K, Hanssen H, Eberhardt K, Vilser W, Schmaderer C, Halle $\mathrm{M}$, et al. Retinal pulse wave velocity in young male normotensive and mildly hypertensive subjects. Microcirculation. (2013) 20:405-15. doi: 10.1111/micc.12036 
65. Avolio A, Jones D, Tafazzoli-Shadpour M. Quantification of alterations in structure and function of elastin in the arterial media. Hypertension. (1998) 32:170-5. doi: 10.1161/01.HYP.32.1.170

66. Kaess BM, Rong J, Larson MG, Hamburg NM, Vita JA, Levy D, et al. Aortic stiffness, blood pressure progression, and incident hypertension. JAMA. (2012) 308:875-81. doi: 10.1001/2012.jama.10503

67. Weisbrod RM, Shiang T, Al Sayah L, Fry JL, Bajpai S, Reinhart-King CA, et al. Arterial stiffening precedes systolic hypertension in diet-induced obesity. Hypertension. 2013:HYPERTENSIONAHA. 113.01744.

68. Liao D, Arnett DK, Tyroler HA, Riley WA, Chambless LE, Szklo M, et al. Arterial stiffness and the development of hypertension: the ARIC study. Hypertension. (1999) 34:201-6. doi: 10.1161/01.HYP.34.2.201

69. Najjar SS, Scuteri A, Shetty V, Wright JG, Muller DC, Fleg JL, et al. Pulse wave velocity is an independent predictor of the longitudinal increase in systolic blood pressure and of incident hypertension in the Baltimore Longitudinal Study of Aging. J Am Coll Cardiol. (2008) 51:1377-83. doi: 10.1016/j.jacc.2007.10.065

70. Lacolley P, Challande P, Osborne-Pellegrin M, Regnault V. Genetics and pathophysiology of arterial stiffness. Cardiovasc Res. (2008) 81:637-48. doi: $10.1093 /$ cvr/cvn353

71. Lacolley P, Regnault V, Segers P, Laurent S. Vascular smooth muscle cells and arterial stiffening: relevance in development, aging, and disease. Physiol Rev. (2017) 97:1555-617. doi: 10.1152/physrev.00003.2017

72. Redheuil A, Yu W-C, Mousseaux E, Harouni AA, Kachenoura N, Wu CO, et al. Age-related changes in aortic arch geometry: relationship with proximal aortic function and left ventricular mass and remodeling. J Am Coll Cardiol. (2011) 58:1262-70. doi: 10.1016/j.jacc.2011.06.012

73. Milan A, Tosello F, Caserta M, Naso D, Puglisi E, Magnino C, et al. Aortic size index enlargement is associated with central hemodynamics in essential hypertension. Hypertens Res. (2011) 34:126-32. doi: 10.1038/hr.2010.185

74. Lam CS, Xanthakis V, Sullivan LM, Lieb W, Aragam J, Redfield MM, et al. Aortic root remodeling over the adult life course: longitudinal data from the Framingham Heart Study. Circulation. (2010) 122:884-90. doi: 10.1161/CIRCULATIONAHA.110.937839

75. Teixido-Tura G, Almeida AL, Choi E-Y, Gjesdal O, Jacobs DR Jr, Dietz HC, et al. Determinants of aortic root dilatation and reference values among young adults over a 20-year period: coronary artery risk development in young adults study. Hypertension. (2015) 66:23-9. doi: 10.1161/HYPERTENSIONAHA.115.05156

76. Torjesen AA, Sigurð*sson S, Westenberg JJ, Gotal JD, Bell V, Aspelund T, et al. Pulse pressure relation to aortic and left ventricular structure in the Age, Gene/Environment Susceptibility (AGES)-Reykjavik Study. Hypertension. (2014) 64:756-61. doi: 10.1161/HYPERTENSIONAHA.114.03870

77. Yano Y, Neeland IJ, Ayers C, Peshock R, Berry JD, Lloyd-Jones DM, et al. Hemodynamic and mechanical properties of the proximal aorta in young and middle-aged adults with isolated systolic hypertension: the Dallas Heart Study. Hypertension. (2017) 70:158-65. doi: 10.1161/HYPERTENSIONAHA.117.09279

78. Farasat SM, Morrell CH, Scuteri A, Ting C-T, Yin FC, Spurgeon HA, et al. Pulse pressure is inversely related to aortic root diameter implications for the pathogenesis of systolic hypertension. Hypertension. (2008) 51:196-202. doi: 10.1161/HYPERTENSIONAHA.107.099515

79. Fortier C, Desjardins M-P, Agharazii M. Aortic-brachial pulse wave velocity ratio: a measure of arterial stiffness gradient not affected by mean arterial pressure. Pulse. (2017) 5:117-24. doi: 10.1159/000480092

80. Fortier C, Mac-Way F, Desmeules S, Marquis K, De Serres SA, Lebel $M$, et al. Aortic-brachial stiffness mismatch and mortality in dialysis population. Hypertension. (2015) 65:378-84. doi: 10.1161/HYPERTENSIONAHA.114.04587

81. Picone DS, Schultz MG, Climie RE, Srikanth V, Sharman JE. Aortic-tobrachial stiffness gradient and kidney function in type 2 diabetes. J Hypertens. (2016) 34:1132-9. doi: 10.1097/HJH.0000000000000916

82. Schultz MG, Hughes AD, Davies JE, Sharman JE. Associations and clinical relevance of aortic-brachial artery stiffness mismatch, aortic reservoir function, and central pressure augmentation. Am J Physiol Heart Circ Physiol. (2015) 309:H1225-33. doi: 10.1152/ajpheart.00317.2015

83. Baksi AJ, Davies JE, Hadjiloizou N, Baruah R, Unsworth B, Foale RA, et al. Attenuation of reflected waves in man during retrograde propagation from femoral artery to proximal aorta. Int J Cardiol. (2016) 202:441-5. doi: 10.1016/j.ijcard.2015.09.064

84. Davies JE, Alastruey J, Francis DP, Hadjiloizou N, Whinnett ZI, Manisty $\mathrm{CH}$, et al. Attenuation of wave reflection by wave entrapment creates a "horizon effect" in the human aorta. Hypertension. (2012) 60:778-85. doi: 10.1161/HYPERTENSIONAHA.111.180604

85. Hughes AD, Park C, Davies J, Francis D, Thom SAM, Mayet J, et al. Limitations of augmentation index in the assessment of wave reflection in normotensive healthy individuals. PLoS ONE. (2013) 8:e59371. doi: 10.1371/journal.pone.0059371

86. Walshe TE, Connell P, Cryan L, Ferguson G, O’brien C, Cahill PA. The role of pulsatile flow in controlling microvascular retinal endothelial and pericyte cell apoptosis and proliferation. Cardiovas Res. (2010) 89:661-70. doi: $10.1093 / \mathrm{cvr} / \mathrm{cvq} 341$

87. Connell P, Walshe T, Ferguson G, Gao W, O’Brien C, Cahill PA. Elevated glucose attenuates agonist-and flow-stimulated endothelial nitric oxide synthase activity in microvascular retinal endothelial cells. Endothelium. (2007) 14:17-24. doi: 10.1080/10623320601177213

88. Suematsu M, Suzuki H, Delano FA, Schmid-Schönbein GW. The inflammatory aspect of the microcirculation in hypertension: oxidative stress, leukocytes/endothelial interaction, apoptosis. Microcirculation. (2002) 9:259-76. doi: 10.1038/sj.mn.7800141

89. Marin T, Gongol B, Chen Z, Woo B, Subramaniam S, Chien S, et al. Mechanosensitive microRNAs-role in endothelial responses to shear stress and redox state. Free Radic Biol Med. (2013) 64:61-8. doi: 10.1016/j.freeradbiomed.2013.05.034

90. Millasseau S, Agnoletti D. Non-invasive estimation of aortic blood pressures: a close look at current devices and methods. Curr Pharm Des. (2015) 21:709-18. doi: 10.2174/1381612820666141023163748

91. Davies JE, Baksi J, Francis DP, Hadjiloizou N, Whinnett ZI, Manisty CH, et al. The arterial reservoir pressure increases with aging and is the major determinant of the aortic augmentation index. Am J Physiol Heart Circ Physiol. (2009) 298:H580-6. doi: 10.1152/ajpheart.00875.2009

92. Heusinkveld MH, Delhaas T, Lumens J, Huberts W, Spronck B, Hughes AD, et al. Augmentation index is not a proxy for wave reflection magnitude: mechanistic analysis using a computational model. J Appl Physiol. (2019) 127:491-500. doi: 10.1152/japplphysiol.00769.2018

93. Vlachopoulos C, Aznaouridis K, O’Rourke MF, Safar ME, Baou K, Stefanadis C. Prediction of cardiovascular events and all-cause mortality with central haemodynamics: a systematic review and meta-analysis. Eur Heart J. (2010) 31:1865-71. doi: 10.1093/eurheartj/ehq024

94. Hametner B, Wassertheurer S. Pulse waveform analysis: is it ready for prime time? Curr Hypertens Rep. (2017) 19:73. doi: 10.1007/s11906-0170769-3

95. Segers P, O'Rourke MF, Parker K, Westerhof N, Hughes A, AguadoSierra J, et al. Towards a consensus on the understanding and analysis of the pulse waveform: results from the 2016 workshop on arterial hemodynamics: past, present and future. Artery Res. (2017) 18:75-80. doi: 10.1016/j.artres.2017.03.004

96. Westerhof N, Stergiopulos N, Noble MI, Westerhof BE. Wave Travel and Pulse Wave Velocity. In: Snapshots of Hemodynamics. Cham: Springer International Publishing AG (2019). p. 165-73. doi: 10.1007/978-3-319-91932-4_21

97. Parker KH. An introduction to wave intensity analysis. Med Biol Eng Comp. (2009) 47:175-88. doi: 10.1007/s11517-009-0439-y

98. Chirinos JA, Kips JG, Jacobs DR, Brumback L, Duprez DA, Kronmal R, et al. Arterial wave reflections and incident cardiovascular events and heart failure: MESA (Multiethnic Study of Atherosclerosis). J Am Coll Cardiol. (2012) 60:2170-7. doi: 10.1016/j.jacc.2012.07.054

99. Cooper LL, Rong J, Benjamin EJ, Larson MG, Levy D, Vita JA, et al. Components of hemodynamic load and cardiovascular events: the Framingham Heart Study. Circulation. (2015) 131:354-61. doi: 10.1161/CIRCULATIONAHA.114.011357

100. Parker KH, Jones CJ, Dawson JR, Gibson DG. What stops the flow of blood from the heart? Heart Vessels. (1988) 4:241-5. doi: 10.1007/BF02058593

101. Hughes AD, Parker KH, Davies JE. Waves in arteries: a review of wave intensity analysis in the systemic and coronary circulations. Artery Res. (2008) 2:51-9. doi: 10.1016/j.artres.2008.02.002 
102. Ohte N, Narita H, Sugawara M, Niki K, Okada T, Harada A, et al. Clinical usefulness of carotid arterial wave intensity in assessing left ventricular systolic and early diastolic performance. Heart Vessels. (2003) 18:107-11. doi: 10.1007/s00380-003-0700-5

103. Henein MY, Tat K, Parker KH, Gibson DG. Arterial waves in humans during peripheral vascular surgery. Clin Sci. (2001) 101:749-57. doi: $10.1042 / \mathrm{cs} 1010749$

104. Sugawara M, Niki K, Ohte N, Okada T, Harada A. Clinical usefulness of wave intensity analysis. Med Biol Eng Comp. (2009) 47:197-206. doi: 10.1007/s11517-008-0388-x

105. Bleasdale RA, Mumford CE, Campbell RI, Fraser AG, Jones CJ, Frenneaux MP. Wave intensity analysis from the common carotid artery: a new noninvasive index of cerebral vasomotor tone. Heart Vessels. (2003) 18:2026. doi: 10.1007/s00380-003-0711-2

106. Manisty $\mathrm{CH}$, Zambanini A, Parker KH, Davies JE, Francis DP, Mayet J, et al. Differences in the magnitude of wave reflection account for differential effects of amlodipine-versus atenololbased regimens on central blood pressure: an Anglo-Scandinavian Cardiac Outcome Trial substudy. Hypertension. (2009) 54:724-30. doi: 10.1161/HYPERTENSIONAHA.108.125740

107. Manisty C, Mayet J, Tapp RJ, Parker KH, Sever P, Poulter NH, et al. Wave reflection predicts cardiovascular events in hypertensive individuals independent of blood pressure and other cardiovascular risk factors: an ASCOT (Anglo-Scandinavian Cardiac Outcome Trial) substudy. J Am Coll Cardiol. (2010) 56:24-30. doi: 10.1016/j.jacc.2010.03.030

108. Chiesa ST, Masi S, Shipley MJ, Ellins EA, Fraser AG, Hughes AD, et al. Carotid artery wave intensity in mid-to late-life predicts cognitive decline: the Whitehall II study. Eur Heart J. (2019) 40:2300-2309 doi: 10.1093/eurheartj/ehz189

109. Penny DJ, Mynard JP, Smolich JJ. Aortic wave intensity analysis of ventricular-vascular interaction during incremental dobutamine infusion in adult sheep. Am J Physiol Heart Circ Physiol. (2008) 294:H481-9. doi: 10.1152/ajpheart.00962.2006

110. Zambanini A, Cunningham SL, Parker KH, Khir AW, McG. Thom S, Hughes $\mathrm{AD}$. Wave-energy patterns in carotid, brachial, and radial arteries: a noninvasive approach using wave-intensity analysis. Am J Physiol Heart Circ Physiol. (2005) 289:H270-6. doi: 10.1152/ajpheart.00636.2003

111. Curtis SL, Zambanini A, Mayet J, McG Thom SA, Foale R, Parker KH, et al. Reduced systolic wave generation and increased peripheral wave reflection in chronic heart failure. Am J Physiol Heart Circ Physiol. (2007) 293:H557-62. doi: 10.1152/ajpheart.01095.2006

112. Feng J, Khir A. Determination of wave speed and wave separation in the arteries using diameter and velocity. J Biomech. (2010) 43:455-62. doi: 10.1016/j.jbiomech.2009.09.046

113. Borlotti A, Khir AW, Rietzschel ER, De Buyzere ML, Vermeersch S, Segers P. Noninvasive determination of local pulse wave velocity and wave intensity: changes with age and gender in the carotid and femoral arteries of healthy human. J Appl Physiol. (2012) 113:727-35. doi: 10.1152/japplphysiol.00164.2012

114. Di Lascio N, Kusmic C, Stea F, Faita F. Wave intensity analysis in mice: agerelated changes in WIA peaks and correlation with cardiac indexes. Heart Vessels. (2017) 32:474-83. doi: 10.1007/s00380-016-0914-y

115. Mynard JP, Smolich JJ. Novel wave power analysis linking pressure-flow waves, wave potential, and the forward and backward components of hydraulic power. Am J Physiol Heart Circ Physiol. (2016) 310:H1026-38. doi: 10.1152/ajpheart.00954.2015

116. Kowalski R, Lee MG, Doyle LW, Cheong JL, Smolich JJ, d'Udekem $\mathrm{Y}$, et al. Reduced aortic distensibility is associated with higher aortocarotid wave transmission and central aortic systolic pressure in young adults after coarctation repair. J Am Heart Assoc. (2019) 8:e011411. doi: 10.1161/JAHA.118.011411

117. Hametner B, Bauer A, Wassertheurer S. Unveiling the vascular mechanisms behind long-term effects of coarctation treatment using pulse wave dynamics. Am Heart Assoc. (2019) 8:e012278. doi: 10.1161/JAHA.119.012278

118. Brundel M, Kappelle LJ, Biessels GJ. Brain imaging in type 2 diabetes. Eur Neuropsychopharmacol. (2014) 24:1967-81. doi: 10.1016/j.euroneuro.2014.01.023
119. Halani S, Kwinta JB, Golestani AM, Khatamian YB, Chen JJ. Comparing cerebrovascular reactivity measured using BOLD and cerebral blood flow MRI: the effect of basal vascular tension on vasodilatory and vasoconstrictive reactivity. Neuroimage. (2015) 110:110-23. doi: 10.1016/j.neuroimage.2015.01.050

120. Heijtel D, Mutsaerts HJ, Bakker E, Schober P, Stevens M, Petersen E, et al. Accuracy and precision of pseudo-continuous arterial spin labeling perfusion during baseline and hypercapnia: a head-to-head comparison with $15 \mathrm{O}$ H2O positron emission tomography. Neuroimage. (2014) 92:182-92. doi: 10.1016/j.neuroimage.2014.02.011

121. Leung J, Behpour A, Sokol N, Mohanta A, Kassner A. Assessment of intracranial blood flow velocities using a computer controlled vasoactive stimulus: a comparison between phase contrast magnetic resonance angiography and transcranial Doppler ultrasonography. J Magn Reson Imaging. (2013) 38:733-8. doi: 10.1002/jmri.23911

122. Geurts LJ, Bhogal AA, Siero JC, Luijten PR, Biessels GJ, Zwanenburg JJ. Vascular reactivity in small cerebral perforating arteries with $7 \mathrm{~T}$ phase contrast MRI-A proof of concept study. NeuroImage. (2018) 172:470-7. doi: 10.1016/j.neuroimage.2018.01.055

123. Mitchell GF. Aortic stiffness, pressure and flow pulsatility, and target organ damage. J Appl Physiol. (2018) 125:1871-80. doi: 10.1152/japplphysiol.00108.2018

124. Dux-Santoy L, Guala A, Teixidó-Turà G, Ruiz-Muñoz A, Maldonado G, Villalva $\mathrm{N}$, et al. Increased rotational flow in the proximal aortic arch is associated with its dilation in bicuspid aortic valve disease. Eur Heart J Cardiovasc Imaging. (2019). doi: 10.1093/ehjci/jez046. [Epub ahead of print].

125. Rodríguez-Palomares JF, Dux-Santoy L, Guala A, Kale R, Maldonado G, Teixidó-Turà G, et al. Aortic flow patterns and wall shear stress maps by $4 \mathrm{D}$ flow cardiovascular magnetic resonance in the assessment of aortic dilatation in bicuspid aortic valve disease. J Cardiovasc Magn Reson. (2018) 20:28. doi: 10.1186/s12968-018-0451-1

126. Guzzardi DG, Barker AJ, Van Ooij P, Malaisrie SC, Puthumana JJ, Belke $\mathrm{DD}$, et al. Valve-related hemodynamics mediate human bicuspid aortopathy: insights from wall shear stress mapping. J Am Coll Cardiol. (2015) 66:892900. doi: 10.1016/j.jacc.2015.06.1310

127. van Bussel FC, Backes WH, Hofman PA, van Oostenbrugge RJ, van Boxtel MP, Verhey FR, et al. Cerebral pathology and cognition in diabetes: the merits of multiparametric neuroimaging. Front Neurosci. (2017) 11:188. doi: 10.3389/fnins.2017.00188

128. Iima M, Le Bihan D. Clinical intravoxel incoherent motion and diffusion MR imaging: past, present, and future. Radiology. (2015) 278:13-32. doi: 10.1148/radiol.2015150244

129. Dixon W. Separation of diffusion and perfusion in intravoxel incoherent motion MR imaging: a modest proposal with tremendous potential. Radiology. (1988) 168:566-7. doi: 10.1148/radiology.168.2.3393682

130. van Bussel FC, Backes WH, Hofman PA, van Oostenbrugge RJ, Kessels AG, van Boxtel MP, et al. On the interplay of microvasculature, parenchyma, and memory in type 2 diabetes. Diab Care. (2015) 38:876-82. doi: $10.2337 / \mathrm{dc} 14-2043$

131. Geurts LJ, Zwanenburg JJ, Klijn CJ, Luijten PR, Biessels GJ. Higher pulsatility in cerebral perforating arteries in patients with small vessel disease related stroke, a 7T MRI study. Stroke. (2019) 50:62-8. doi: 10.1161/STROKEAHA.118.022516

132. Chung CP, Lee HY, Lin PC, Wang PN. Cerebral artery pulsatility is associated with cognitive impairment and predicts dementia in individuals with subjective memory decline or mild cognitive impairment. J Alzheimers Dis. (2017) 60:625-32. doi: 10.3233/JAD-170349

133. Krutzén E, Bäck S-E, Nilsson-Ehle I, Nilsson-Ehle P. Plasma clearance of a new contrast agent, iohexol: a method for the assessment of glomerular filtration rate. J Lab Clin Med. (1984) 104:955-61.

134. Dick A, Davies C. Measurement of the glomerular filtration rate and the effective renal plasma flow using sodium thiosulphate and p-AminoHippuric Acid. J Clin Pathol. (1949) 2:67-72. doi: 10.1136/jcp.2.1.67

135. Bruno RM, Reesink K, Ghiadoni L. Advances in the non-invasive assessment of vascular dysfunction in metabolic syndrome and diabetes: focus on endothelium, carotid mechanics and renal vessels. Nutr Metab Cardiovasc Dis. (2017) 27:121-8. doi: 10.1016/j.numecd.2016.09.004 
136. Lee VS, Rusinek H, Bokacheva L, Huang AJ, Oesingmann N, Chen Q, et al. Renal function measurements from MR renography and a simplified multicompartmental model. Am J Physiol Renal Physiol. (2007) 292:F154859. doi: 10.1152/ajprenal.00347.2006

137. Hashimoto J, Ito S. Central pulse pressure and aortic stiffness determine renal hemodynamics: pathophysiological implication for microalbuminuria in hypertension. Hypertension. (2011) 58:839-46. doi: 10.1161/HYPERTENSIONAHA.111.177469

138. Bruno RM, Daghini E, Landini L, Versari D, Salvati A, Santini E, et al. Dynamic evaluation of renal resistive index in normoalbuminuric patients with newly diagnosed hypertension or type 2 diabetes. Diabetologia. (2011) 54:2430-9. doi: 10.1007/s00125-011-2148-y

139. Stea F, Sgrò M, Faita F, Bruno RM, Cartoni G, Armenia S, et al. Relationship between wave reflection and renal damage in hypertensive patients: a retrospective analysis. J Hypertens. (2013) 31:2418-24. doi: 10.1097/HJH.0b013e3283652ca7

140. O'Neill WC. Renal resistive index: a case of mistaken identity. Hypertension. (2014) 64:915-7. doi: 10.1161/HYPERTENSIONAHA.114.04183

141. Yura T, Yuasa S, Fukunaga M, Badr KF, Matsuo H. Role for Doppler ultrasound in the assessment of renal circulation: effects of dopamine and dobutamine on renal hemodynamics in humans. Nephron. (1995) 71:168-75. doi: 10.1159/000188707

142. Schober P, Loer SA, Schwarte LA. Transesophageal Doppler devices: a technical review. J Clin Monit Comput. (2009) 23:391-401. doi: 10.1007/s10877-009-9204-x

143. Nosadini R, Velussi M, Brocco E, Abaterusso C, Carraro A, Piarulli F, et al. Increased renal arterial resistance predicts the course of renal function in type 2 diabetes with microalbuminuria. Diabetes. (2006) 55:234-9. doi: 10.2337/diabetes.55.01.06.db05-0881

144. Toledo C, Thomas G, Schold JD, Arrigain S, Gornik HL, Nally JV, et al. Renal resistive index and mortality in chronic kidney disease. Hypertension. (2015) 66:382-8. doi: 10.1161/HYPERTENSIONAHA.115.05536

145. Bruno R, Salvati A, Barzacchi M, Raimo K, Taddei S, Ghiadoni L, et al. Predictive value of dynamic renal resistive index (DRIN) for renal outcome in type 2 diabetes and essential hypertension: a prospective study. Cardiovasc Diabetol. (2015) 14:63. doi: 10.1186/s12933-0150227-y

146. Houben AJ, Martens RJ, Stehouwer CD. Assessing microvascular function in humans from a chronic disease perspective. J Am Soc Nephrol. (2017) 28:3461-72. doi: 10.1681/ASN.2017020157

147. Cheung CY-1, Ikram MK, Chen C, Wong TY. Imaging retina to study dementia and stroke. Prog Retin Eye Res. (2017) 57:89-107. doi: 10.1016/j.preteyeres.2017.01.001

148. Gunthner R, Hanssen H, Hauser C, Angermann S, Lorenz $\mathrm{G}$, Kemmner $\mathrm{S}$, et al. Impaired retinal vessel dilation predicts mortality in end-stage renal disease. Circ Res. (2019) 124:1796-807. doi: 10.1161/CIRCRESAHA.118.314318

149. Khoobehi B, Peyman GA. Fluorescent labeling of blood cells for evaluation of retinal and choroidal circulation. Ophthalmic Surg Lasers Imaging Retina. (1999) 30:140-5.

150. Clermont AC, Aiello LP, Mori F, Aiello LM, Bursell S-E. Vascular endothelial growth factor and severity of nonproliferative diabetic retinopathy mediate retinal hemodynamics in vivo: a potential role for vascular endothelial growth factor in the progression of nonproliferative diabetic retinopathy. Am J Ophthalmol. (1997) 124:433-46. doi: 10.1016/S0002-9394(14)70860-8

151. Nishiwaki H, Ogura Y, Kimura H, Kiryu J, Honda Y. Quantitative evaluation of leukocyte dynamics in retinal microcirculation. Invest Ophthalmol Vis Sci. (1995) 36:123-30.
152. Klufas MA, Yannuzzi NA, Pang CE, Srinivas S, Sadda SR, Freund KB, et al. Feasibility and clinical utility of ultra-widefield indocyanine green angiography. Retina. (2015) 35:508-20. doi: 10.1097/IAE.0000000000000318

153. Martin JA, Roorda A. Direct and noninvasive assessment of parafoveal capillary leukocyte velocity. Ophthalmology. (2005) 112:2219-24. doi: 10.1016/j.ophtha.2005.06.033

154. De Carlo TE, Romano A, Waheed NK, Duker JS. A review of optical coherence tomography angiography (OCTA). Int J Retina Vitreous. (2015) 1:5. doi: 10.1186/s40942-015-0005-8

155. Ormerod LD, Fariza E, Webb RH. Dynamics of external ocular blood flow studied by scanning angiographic microscopy. Eye. (1995) 9:605-14. doi: 10.1038/eye.1995.148

156. Riva CE, Grunwald JE, Sinclair SH, Petrig B. Blood velocity and volumetric flow rate in human retinal vessels. Invest Ophthalmol Vis Sci. (1985) 26:112432.

157. Riva C, Harino S, Petrig B, Shonat R. Laser Doppler flowmetry in the optic nerve. Exp Eye Res. (1992) 55:499-506. doi: 10.1016/0014-4835(92)90123-A

158. Sullivan P, Cioffi G, Wang L, Johnson C, Van Buskirk E, Sherman K, et al. The influence of ocular pulsatility on scanning laser Doppler flowmetry. Am J Ophthalmol. (1999) 128:81-7. doi: 10.1016/S0002-9394(99)00072-0

159. Yazdanfar S, Rollins AM, Izatt JA. In vivo imaging of human retinal flow dynamics by color Doppler optical coherence tomography. Archiv Ophthalmol. (2003) 121:235-9. doi: 10.1001/archopht.121.2.235

160. Puyo L, Paques M, Fink M, Sahel J-A, Atlan M. Waveform analysis of human retinal and choroidal blood flow with laser Doppler holography. Biomed Opt Expr. (2019) 10:4942-63. doi: 10.1364/BOE.10.004942

161. Shiba T, Takahashi M, Shiba C, Matsumoto T, Hori Y. The relationships between the pulsatile flow form of ocular microcirculation by laser speckle flowgraphy and the left ventricular end-diastolic pressure and mass. Int $J$ Cardiovasc Imaging. (2018) 34:1715-23. doi: 10.1007/s10554-018-1388-Z

162. Wong TY, Klein R, Couper DJ, Cooper LS, Shahar E, Hubbard LD, et al. Retinal microvascular abnormalities and incident stroke: the atherosclerosis risk in communities study. Lancet. (2001) 358:1134-40. doi: 10.1016/S0140-6736(01)06253-5

163. Wong TY, Klein R, Sharrett AR, Duncan BB, Couper DJ, Tielsch JM, et al. Retinal arteriolar narrowing and risk of coronary heart disease in men and women: the Atherosclerosis Risk in Communities study. JAMA. (2002) 287:1153-9. doi: 10.1001/jama.287.9.1153

164. Nägele MP, Barthelmes J, Ludovici V, Cantatore S, von Eckardstein A, Enseleit F, et al. Retinal microvascular dysfunction in heart failure. Eur Heart J. (2017) 39:47-56. doi: 10.1093/eurheartj/ehx565

165. Chandra A, Seidelmann SB, Claggett BL, Klein BE, Klein R, Shah AM, et al. The association of retinal vessel calibres with heart failure and longterm alterations in cardiac structure and function: the Atherosclerosis Risk in Communities (ARIC) study. Eur J Heart Failure. (2019) 21:1207-15. doi: 10.1002/ejhf.1564

Conflict of Interest: The authors declare that the research was conducted in the absence of any commercial or financial relationships that could be construed as a potential conflict of interest.

Copyright (c) 2019 Climie, Gallo, Picone, Di Lascio, van Sloten, Guala, Mayer, Hametner and Bruno. This is an open-access article distributed under the terms of the Creative Commons Attribution License (CC BY). The use, distribution or reproduction in other forums is permitted, provided the original author(s) and the copyright owner(s) are credited and that the original publication in this journal is cited, in accordance with accepted academic practice. No use, distribution or reproduction is permitted which does not comply with these terms. 